\title{
3-Substituted $N$-Benzylpyrazine-2-carboxamide Derivatives: Synthesis, Antimycobacterial and Antibacterial Evaluation
}

\author{
Lucia Semelková ${ }^{1, *}$, Ondřej Jand'ourek ${ }^{1}$, Klára Konečná ${ }^{1}$, Pavla Paterová ${ }^{2}$, Lucie Navrátilová ${ }^{1}$, \\ František Trejtnar ${ }^{1}$, Vladimír Kubíček ${ }^{1}$, Jiří Kuneš ${ }^{1}$, Martin Doležal ${ }^{1}$ and Jan Zitko ${ }^{1, *}$ \\ 1 Faculty of Pharmacy in Hradec Králové, Charles University, Heyrovského 1203, 50005 Hradec Králové, \\ Czech Republic; JANDO6AA@faf.cuni.cz (O.J.); konecna@faf.cuni.cz (K.K.); navrat12@faf.cuni.cz (L.N.); \\ trejtnarf@faf.cuni.cz (F.T.); kubicek@faf.cuni.cz (V.K.); kunes@faf.cuni.cz (J.K.); dolezalm@faf.cuni.cz (M.D.) \\ 2 Department of Clinical Microbiology, University Hospital, Sokolská 581, 50005 Hradec Králové, \\ Czech Republic; pavla.paterova@fnhk.cz \\ * Correspondence: semelkol@faf.cuni.cz (L.S.); jan.zitko@faf.cuni.cz (J.Z.); Tel.: +420-495-067-275 (L.S.)
}

Academic Editor: Derek J. McPhee

Received: 6 February 2017; Accepted: 17 March 2017; Published: 21 March 2017

\begin{abstract}
A series of substituted $N$-benzyl-3-chloropyrazine-2-carboxamides were prepared as positional isomers of 5-chloro and 6-chloro derivatives, prepared previously. During the aminolysis of the acyl chloride, the simultaneous substitution of chlorine with benzylamino moiety gave rise to $\mathrm{N}$-benzyl-3-(benzylamino)pyrazine-2-carboxamides as side products, in some cases. Although not initially planned, the reaction conditions were modified to populate this double substituted series. The final compounds were tested against four mycobacterial strains. $N$-(2-methylbenzyl) -3-((2-methylbenzyl)amino)pyrazine-2-carboxamide (1a) and $N$-(3,4dichlorobenzyl)-3-((3,4-dichlorobenzyl)amino)pyrazine-2-carboxamide (9a) proved to be the most effective against Mycobacterium tuberculosis $\mathrm{H} 37 \mathrm{Rv}$, with $\mathrm{MIC}=12.5 \mu \mathrm{g} \cdot \mathrm{mL}^{-1}$. Compounds were screened for antibacterial activity. The most active compound was 3-chloro- $\mathrm{N}$-(2-chlorobenzyl) pyrazine-2-carboxamide (5) against Staphylococcus aureus with MIC $=7.81 \mu \mathrm{M}$, and Staphylococcus epidermidis with MIC $=15.62 \mu \mathrm{M}$. HepG2 in vitro cytotoxicity was evaluated for the most active compounds; however, no significant toxicity was detected. Compound 9a was docked to several conformations of the enoyl-ACP-reductase of Mycobacterium tuberculosis. In some cases, it was capable of $H$-bond interactions, typical for most of the known inhibitors.
\end{abstract}

Keywords: pyrazinamide derivatives; benzylamines; antibacterial activity; antimycobacterial activity; cytotoxicity; enoyl-ACP-reductase; molecular docking

\section{Introduction}

Every living organism is bound to evolve in order to survive. Although it is a natural process spanning millions of years, in the case of pathogenic microorganisms, this adaptation for survival is rather undesirable from a human point of view. Microorganisms have developed a range of protective mechanisms to deactivate, remove, or otherwise circumvent the toxicity of anti-infective compounds [1]. The appearance of resistance is positively linked to the frequency of use of such an anti-infective. Practically, resistance to any clinically used anti-infective drug will develop sooner or later [2]. Increasing rates of microbial resistance to both commonly used and reserved agents highlight the necessity to develop new effective compounds.

According to the WHO Global Tuberculosis Report 2016, it was estimated that there were 10.4 million new tuberculosis (TB) cases and 1.4 million TB associated deaths in 2015. Although TB 
incidence rates have been slowly declining for several consecutive years and an estimated 43 million lives were saved between 2000 and 2014 through effective diagnosis and treatment, the presence of resistant forms and co-infection with HIV pose a considerable threat to successful treatment. The percentage of new TB cases that were multidrug-resistant (MDR-TB) was 3.3\% in 2014, whereas HIV-positive patients represented $12 \%$ of the 9.6 million people who developed TB [3]. Pyrazinamide (PZA), as a fist-line antitubercular drug, has gained an irreplaceable role in TB therapy and has been subjected to various chemical modifications [4-7]. Although PZA has been used for over sixty years [8], it is still not completely known how PZA acts in a mycobacterial cell [8-12].

5-Chloropyrazinamide, as a fatty acid synthase I (FAS I, involved in mycolic acids biosynthesis) inhibitor [10], was a pattern for a series of 5- or 6-chloropyrazine-2-carboxamides with $N$-benzylamino substitution (Figure 1), prepared and previously reported by Servusová et al. [13,14]. 5-Cl derivatives with 4-Cl, 4-Br, or 2,4-diCl substitution on the phenyl ring exerted antimycobacterial activity with a minimum inhibitory concentration (MIC) of $12.5 \mu \mathrm{g} \cdot \mathrm{mL}^{-1}$, and 6- $\mathrm{Cl}$ derivatives with $4-\mathrm{OCH}_{3}, 3-\mathrm{CF}_{3}$, or 4- $\mathrm{Cl}$ substitution on the phenyl ring showed an MIC of $6.25-12.5 \mu \mathrm{g} \cdot \mathrm{mL}^{-1}[13,14]$. As reported in this article, compounds 1-13 comprising 3-Cl-pyrazine moiety were originally designed as positional isomers with respect to the chloro substitution on the pyrazine ring, in order to study the effect of positional isomerism on anti-infective activity.
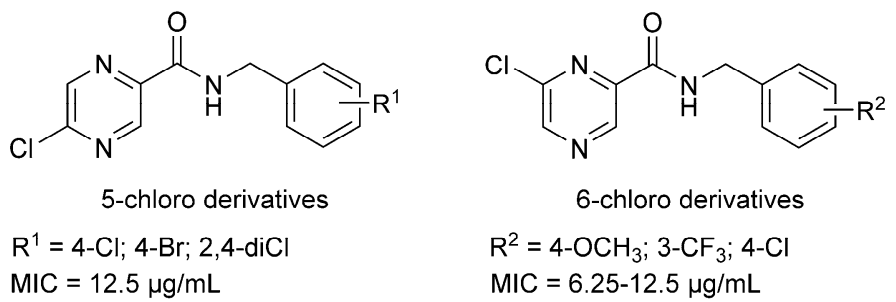

Figure 1. Structures of previously reported chloropyrazine-2-carboxamide derivatives with in vitro antimycobacterial activity (M. tuberculosis H3Rv).

However, dibenzyl substituted derivatives 1a-13a, which initially originated as side-products of intended monosubstituted derivatives, turned out to be more effective compounds.

As a complementary test, all of our compounds were subject to initial screening for in vitro activity against clinically important Gram-positive and Gram-negative bacteria, including methicillin-resistant Staphylococcus aureus (MRSA). Any potential hit compound against MRSA would be highly appreciated as MRSA has become one of the most feared pathogens in the last few decades [14].

\section{Results and Discussion}

\subsection{Chemistry}

Substituted N-benzyl-3-chloropyrazine-2-carboxamides 1-13 were prepared by a three-step procedure (Scheme 1), according to Ref. [15]. The initial 3-chloropyrazine-2-carbonitrile (Fluorochem Ltd., Derbysshire, UK) was hydrolysed in $10 \%(\mathrm{~m} / \mathrm{m})$ aqueous $\mathrm{NaOH}$ solution. After $7 \mathrm{~h}$, the reaction mixture was acidified with $10 \% \mathrm{HCl}$ to $\mathrm{pH} 3$, to obtain crystals of 3-chloropyrazine-2-carboxylic acid (3-Cl-POA), which were then filtered and dried. In the following step, 3-Cl-POA was treated with $\mathrm{SOCl}_{2}$ in the presence of a catalytic amount of $N, N$-dimethylformamide (DMF) in toluene under reflux for one hour, producing 3-chloropyrazine-2-carbonyl chloride, which was reacted with substituted benzylamine in the presence of triethylamine (TEA) in acetone at room temperature overnight, to obtain 1-13. In the process of amide bond formation with 2-methyl-, 4-methyl-, and 4-methoxybenzylamine, corresponding N-benzyl-3-(benzylamino)pyrazine-2-carboxamides 1a-3a were formed simultaneously with 1-3 as desired side-products in a molar ratio of approximately 2:3, with an excess of 1a-3a. The side-products could be easily detected by TLC and easily separated by flash-chromatography. We decided to complete the disubstituted series. N-Benzyl-3-(benzylamino)pyrazine-2-carboxamides 
5a-13a were afforded via the aminodehalogenation of 5-13, with the corresponding substituted benzylamine and pyridine in methanol under microwave conditions $\left(150^{\circ} \mathrm{C}, 30 \mathrm{~min}\right.$, power output $100 \mathrm{~W}$, focused field) (Scheme 1d). However, compounds $4 \mathbf{a}\left(\mathrm{R}^{1,2}=2,4-\mathrm{OCH}_{3}\right), 8 \mathbf{a}\left(\mathrm{R}^{1,2}=2,4-\mathrm{Cl}\right)$ and 12a $\left(\mathrm{R}^{1,2}=3-\mathrm{CF}_{3}\right)$ could not be prepared under the chosen conditions. This might have been due to the electron-withdrawing effects of $\mathrm{CF}_{3}$ substitution and/or the steric hindrance of large substituents in the ortho position of the phenyl ring. All prepared compounds (Table 1) were characterized by ${ }^{1} \mathrm{H}-$, ${ }^{13} \mathrm{C}-\mathrm{NMR}$, and IR spectroscopy, their melting point, and elemental analysis. All results were fully in accordance with the proposed structures.

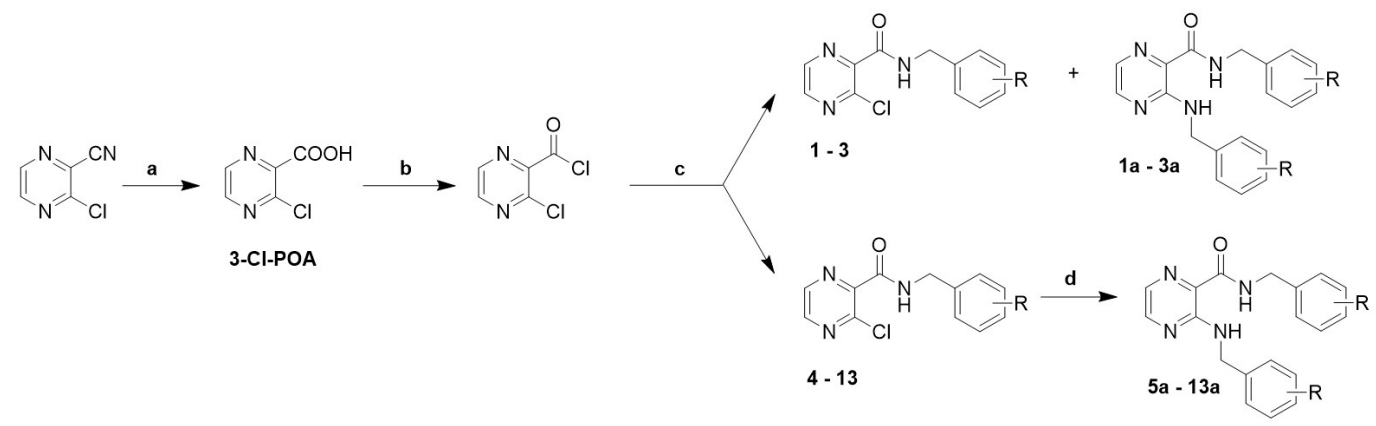

Scheme 1. Synthesis of compounds 1-13 and 1a-13a. Reagents and conditions: (a) $10 \%$ aq. sol. $\mathrm{NaOH}$, reflux $7 \mathrm{~h}$, then $10 \%$ aq. sol. $\mathrm{HCl}$; (b) $\mathrm{SOCl}_{2}$, DMF, toluene, $95^{\circ} \mathrm{C}, 1 \mathrm{~h}$; (c) substituted benzylamine, TEA, acetone, RT, overnight; (d) substituted benzylamine, pyridine, methanol, $\mathrm{MW}: 150^{\circ} \mathrm{C}, 30 \mathrm{~min}, 100 \mathrm{~W}$.

Table 1. Prepared structures, calculated $(C \log P)$ and measured $(\log k)$ lipophilicity parameters, and antimycobacterial activity against $M$. tuberculosis $\mathrm{H} 37 \mathrm{Rv}$ and M. smegmatis.

\begin{tabular}{|c|c|c|c|c|c|c|c|}
\hline \multirow{2}{*}{ No. } & \multirow{2}{*}{$\mathrm{R}^{1}$} & \multirow{2}{*}{$\mathbf{R}^{2}$} & \multirow{2}{*}{ MW } & \multirow{2}{*}{$\mathrm{C} \log P$} & \multirow{2}{*}{$\log k$} & \multicolumn{2}{|c|}{$\operatorname{MIC}\left(\mu \mathrm{g} \cdot \mathrm{mL}^{-1}\right)(\mu \mathrm{M})$} \\
\hline & & & & & & M. tuberculosis & M. smegmatis \\
\hline 1 & $2-\mathrm{CH}_{3}$ & - & 261.71 & 2.004 & 0.009 & $>100$ & 250 \\
\hline 1a & $2-\mathrm{CH}_{3}$ & $2-\mathrm{CH}_{3}$ & 346.43 & 4.862 & 1.459 & $12.5(36)$ & $>500$ \\
\hline 2 & $4-\mathrm{CH}_{3}$ & - & 261.71 & 2.054 & 0.033 & $>100$ & $>500$ \\
\hline $2 a$ & $4-\mathrm{CH}_{3}$ & $4-\mathrm{CH}_{3}$ & 346.43 & 4.962 & 1.517 & $25(72)$ & $>250$ \\
\hline 3 & $4-\mathrm{OCH}_{3}$ & - & 277.71 & 1.474 & -0.202 & $25(90)$ & 125 \\
\hline $3 a$ & $4-\mathrm{OCH}_{3}$ & $4-\mathrm{OCH}_{3}$ & 378.43 & 3.802 & 0.981 & 50 (132) & $>500$ \\
\hline 4 & $2,4-\mathrm{diOCH}_{3}$ & - & 307.73 & 1.563 & -0.095 & $>100$ & $>500$ \\
\hline 5 & $2-\mathrm{Cl}$ & - & 282.12 & 2.268 & 0.033 & $>100$ & 250 \\
\hline $5 a$ & $2-\mathrm{Cl}$ & $2-\mathrm{Cl}$ & 387.26 & 5.390 & 1.542 & $>100$ & $>500$ \\
\hline 6 & $3-\mathrm{Cl}$ & - & 282.12 & 2.268 & 0.060 & 100 & 125 \\
\hline $6 a$ & $3-\mathrm{Cl}$ & $3-\mathrm{Cl}$ & 387.26 & 5.390 & 1.515 & $>100$ & $>500$ \\
\hline 7 & $4-\mathrm{Cl}$ & - & 282.12 & 2.268 & 0.082 & $>100$ & 500 \\
\hline $7 a$ & $4-\mathrm{Cl}$ & $4-\mathrm{Cl}$ & 387.26 & 5.390 & 1.533 & $>50$ & $>250$ \\
\hline 8 & 2,4-diCl & - & 316.57 & 2.981 & 0.375 & $>100$ & 125 \\
\hline 9 & 3,4-diCl & - & 316.57 & 2.861 & 0.309 & 100 & 250 \\
\hline $9 a$ & 3,4-diCl & 3,4-diCl & 456.15 & 6.576 & 1.997 & $12.5(27)$ & $>500$ \\
\hline 10 & $2-\mathrm{F}$ & - & 265.67 & 1.698 & -0.154 & $>100$ & 125 \\
\hline $10 a$ & $2-\mathrm{F}$ & $2-\mathrm{F}$ & 354.36 & 4.250 & 1.108 & $>100$ & $>500$ \\
\hline 11 & $4-\mathrm{F}$ & - & 265.67 & 1.698 & -0.139 & $>100$ & 250 \\
\hline $11 a$ & $4-\mathrm{F}$ & $4-\mathrm{F}$ & 354.36 & 4.250 & 1.058 & $>100$ & $>500$ \\
\hline 12 & $3-\mathrm{CF}_{3}$ & - & 315.68 & 2.438 & 0.110 & $>100$ & 125 \\
\hline 13 & $4-\mathrm{CF}_{3}$ & - & 315.68 & 2.438 & 0.145 & $>100$ & $>500$ \\
\hline $13 a$ & $4-\mathrm{CF}_{3}$ & $4-\mathrm{CF}_{3}$ & 454.38 & 5.730 & 1.593 & $>100$ & $>500$ \\
\hline INH & - & - & - & - & - & 0.2 & $7.8-15.6$ \\
\hline
\end{tabular}




\subsection{Lipophilicity}

The lipophilicity parameters $\log P$ and $C \log P$ were calculated for compounds by ChemDraw Ultra, ver. 14.0. Capacity factor $k$, expressed as $\log k$, was experimentally measured using RP-HPLC. The values of the lipophilicity parameters $C \log P$ and $\log k$ are presented in Table 1 . The relationship between the calculated $C \log P$ and measured $\log k$ is linear, with a regression equation:

$$
\mathrm{C} \log P=(2.149 \pm 0.053) \log k+(2.29 \pm 0.052) ; \mathrm{R}^{2}=0.987 ; \mathrm{s}=0.185 ; \mathrm{F}=1622 ; \mathrm{n}=23
$$

see Figure 2. $C \log P$ takes into consideration the intramolecular hydrogen bond formed between carbonyl oxygen and amine hydrogen (Figure 3). Although the precise algorithm of $C \log P$ calculation is not publically known, its consideration of intramolecular $H$-bond formation can be documented by shifting the benzylamino substituent to various positions of the pyrazine core and comparing the obtained $C \log P$ values. For example, in the case of compound 3a (3-benzylamino derivative) and its 5and 6-positional isomers, the calculated $C \log P$ values are 3.802, 3.725, and 3.752. The increased value for the vicinal disubstituted derivative is caused by the intramolecular $H$-bonding, which decreases the probability to form compound-water $H$-bonds, and therefore, lowers its hydrophilicity. On the contrary, the intramolecular interactions are not recognized by $\log P$ and all the three positional isomers appeared to share the same predicted lipophilicity of $\log P=2.35$. As a result, the calculated $C \log P$ values of the presented compounds have a stronger correlation with the measured $\log k$ than the $\log P$ values.

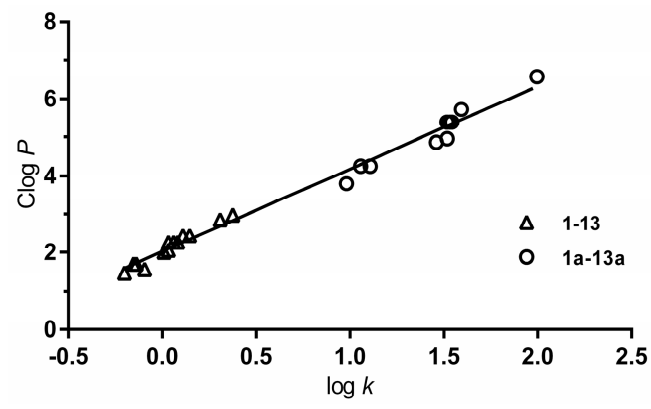

Figure 2. Plot of calculated $C \log P$ on experimentally measured $\log k$ values.

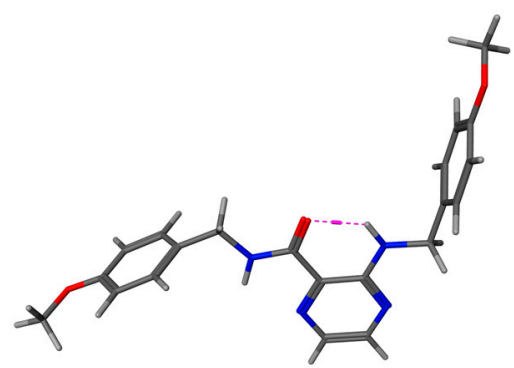

Figure 3. Visualization of the intramolecular hydrogen bond (compound 3a).

\subsection{Biological Evaluation}

\subsubsection{In Vitro Antimycobacterial Activity}

All prepared compounds were tested against Mycobacterium tuberculosis H37Rv (M. tbc), as well as non-tuberculous strains of M. avium and M. kansasii. Additionally, M. smegmatis was used as a fast growing model organism with a highly lipophilic cell wall, similar in composition to the one of $M$. tbc. In vitro screening was performed by a Microplate Alamar Blue Assay (MABA) on whole cells. Results 
were expressed as the minimum inhibitory concentration (MIC) in $\mu \mathrm{g} \cdot \mathrm{mL}^{-1}$. The results for $M$. $t b c$ and M. smegmatis are shown in Table 1.

From the series of 3-chloro derivatives (1-13), the only substance exhibiting significant activity against $M$. tbc $\mathrm{H} 37 \mathrm{Rv}$ was compound 3, with a 4- $\mathrm{OCH}_{3}$ substitution on the benzene ring with $\mathrm{MIC}=25 \mu \mathrm{g} \cdot \mathrm{mL}^{-1}(90 \mu \mathrm{M})$. Relative to the 5- $\mathrm{Cl}$ and $6-\mathrm{Cl}$ derivatives published before [13,14] (Figure 1), the reposition of chlorine to position 3 led to a decrease or loss of antimycobacterial activity against $M . t b c$ H37Rv. The most effective compounds from the 3-benzylamino- $N$-benzylpyrazine-2-carboxamide series (1a-13a) were structures $\mathbf{1 a}\left(\mathrm{R}^{1,2}=2-\mathrm{CH}_{3}\right)$ and 9a $\left(\mathrm{R}^{1,2}=3,4-\mathrm{diCl}\right)$ with $\mathrm{MIC}=12.5 \mu \mathrm{g} \cdot \mathrm{mL}^{-1}(\mathbf{1 a} 36 \mu \mathrm{M} ; 9 \mathbf{9 a} 27 \mu \mathrm{M})$ against M. tbc. The introduction of the second phenyl ring (1a, $\mathbf{2} \mathbf{a}, \mathbf{9 a})$ often led to an increase of antimycobacterial activity when compared to the corresponding single phenyl derivatives $(\mathbf{1}, \mathbf{2}, \mathbf{9})$. The presence of electron-donating substituents $\left(2-\mathrm{CH}_{3}, 4-\mathrm{CH}_{3}, 4-\mathrm{OCH}_{3}\right)$ proved advantageous for the biological effect. Electron-withdrawing substituents $\left(\mathrm{F}, \mathrm{Cl}, \mathrm{CF}_{3}\right)$ did not produce active compounds, even in double phenyl compounds, except for $\mathbf{9 a}(2,4-\mathrm{diCl})$.

The presented compounds were inactive against $M$. kansasii and M. avium, even at the highest tested concentration of $100 \mu \mathrm{g} \cdot \mathrm{mL}^{-1}$ (or $50 \mu \mathrm{g} \cdot \mathrm{mL}^{-1}$ for $7 \mathbf{a}$, due to its lower solubility in DMSO).

Five compounds, namely 3, 6, 8, 10, and 12, showed modest activity against fast growing M. smegmatis with $\mathrm{MIC}=125 \mu \mathrm{g} \cdot \mathrm{mL}^{-1}$. All these compounds belong to the first series of $N$-benzyl-3-chloropyrazine-2-carboxamides. On the contrary to the activity against $M$. $t b c$, the activity against $M$. smegmatis was mutilated by the insertion of the second aromatic ring.

\subsubsection{Antibacterial Activity}

Antibacterial assays were performed against eight clinically significant strains (see Experimental Section). Interesting antibacterial activity against gram-positive Staphylococcus aureus, methicillin-resistant S. aureus (MRSA), and S. epidermidis, was found in the series of 3-chloro derivatives with a single benzene core (see Table 2). Compound $5\left(\mathrm{R}^{1}=2-\mathrm{Cl}\right)$ exerted the highest activity against $S$. aureus with $\mathrm{MIC}=7.81 \mu \mathrm{M}$, and against S. epidermidis with $\mathrm{MIC}=15.62 \mu \mathrm{M}$. Previously published 5-Cl and 6-Cl positional isomers did not show any antibacterial activity in tested concentrations up to $500 \mu \mathrm{M}[13,14]$.

Table 2. Notable antibacterial activities of the effective compounds and standards neomycin and phenoxymethylpenicillin (Penicillin V) against Staphylococcus aureus, methicillin-resistant Staphyloc-occus aureus (MRSA), and Staphylococcus epidermidis.

\begin{tabular}{cccc}
\hline \multirow{2}{*}{ Compound } & \multicolumn{3}{c}{ MIC $(\boldsymbol{\mu M})$ after $\mathbf{2 4} \mathbf{h}$} \\
\cline { 2 - 4 } & S. aureus & MRSA & S. epidermidis \\
\hline $\mathbf{2}$ & 125 & $>500$ & 500 \\
$\mathbf{3}$ & 31.25 & 125 & 250 \\
$\mathbf{3 a}$ & 15.62 & 62.5 & $>500$ \\
$\mathbf{4}$ & 125 & $>500$ & $>500$ \\
$\mathbf{5}$ & 7.81 & 500 & 15.62 \\
$\mathbf{8}$ & 125 & 250 & 125 \\
$\mathbf{9}$ & 62.5 & 250 & 31.25 \\
$\mathbf{1 3}$ & 31.25 & 500 & 62.5 \\
$\mathbf{1 3 a}$ & 62.5 & $>500$ & $>500$ \\
Penicillin V & 0.12 & 62.5 & 3.9 \\
Neomycin & 1.95 & 0.98 & 7.81 \\
\hline
\end{tabular}

The insertion of the second aromatic ring generally decreased the antibacterial activity (with the exception of compound 3a). From the series containing two aromatic moieties (1a-13a), only compounds with 4- $\mathrm{OCH}_{3}(\mathbf{3 a})$ and $4-\mathrm{CF}_{3}$ (13a) displayed antibacterial activity. The most effective compound against MRSA was $3 a\left(\mathrm{R}^{1,2}=4-\mathrm{OCH}_{3}\right)$, with $\mathrm{MIC}=62.5 \mu \mathrm{M}$. 
Compounds not shown in Table 2 did not produce any significant activity against tested bacterial strains.

\subsubsection{Antifungal Activity}

Additionally, the compounds were tested against eight fungal strains (see Experimental Section). No compounds from the presented series showed any activity in antifungal assays up to the highest tested concentration $(500 \mu \mathrm{M})$.

\subsubsection{Cytotoxicity}

The in vitro cytotoxicity of the most active compounds $5,1 \mathbf{a}, \mathbf{3 a}$, and $\mathbf{9 a}$, was evaluated using the standard human hepatocellular carcinoma cell line HepG2. The results of the experiments are presented as a concentration, which reduces the viability of the cell population to $50 \%$ of the maximal viability, $\mathrm{IC}_{50}$ (Table 3). The limited solubility of the compounds $\mathbf{1 a}, \mathbf{3 a}$, and $\mathbf{9 a}$ in the cell culture medium, did not allow a valid calculation of the $\mathrm{IC}_{50}$ value. Compound $5\left(\mathrm{R}^{1}=2-\mathrm{Cl}\right)$, the most active compound against methicillin sensitive $S$. aureus, exerted $\mathrm{IC}_{50}=847.2 \mu \mathrm{M}$, leading to a superior selectivity index, $\mathrm{SI}=\mathrm{IC}_{50} / \mathrm{MIC}=108$.

Table 3. Cytotoxicity of tested substances in HepG2 cells.

\begin{tabular}{cc}
\hline Compound & $\mathrm{IC}_{\mathbf{5 0}}(\boldsymbol{\mu M})$ \\
\hline $\mathbf{5}$ & 847.2 \\
$\mathbf{1 a}$ & $>250^{*}$ \\
$\mathbf{3 a}$ & $>100^{*}$ \\
$\mathbf{9 a}$ & $>100^{*}$ \\
\hline
\end{tabular}

* Measurement at higher concentration not reproducible due to the precipitation of the tested compound in the cell culture medium.

\subsection{Docking Studies}

Based on molecular docking studies, various $N$-benzylpyrazine-2-carboxamides have been previously suggested as potential inhibitors of mycobacterial enoyl-ACP-reductase (InhA) [4], an essential enzyme in the synthesis of mycolic acids and the primary target of the first-line antitubercular isoniazid. In such PZA derivatives, the carbonyl oxygen of the carboxamide moiety was predicted to form an $H$-bond network to Tyr158 and 2'-OH of the ribose of the $\mathrm{NAD}^{+}$cofactor, which is a typical interaction pattern for most of the direct InhA inhibitors derived from triclosan [16].

Most of the compounds presented in this paper with in vitro activity against $M$. tuberculosis were disubstituted derivatives with two large benzyl substituents on two adjacent positions of the pyrazine core. We were interested to find out whether such sterically demanding derivatives would be able to fit in the active site of InhA in a manner similar to smaller PZA derivatives with a single aryl substituent. Therefore, we performed molecular docking of the most active dibenzyl derivative 9a into various conformations of InhA, differing in the size of the active site cavity, which is formed by the highly flexible substrate-binding loop (Figure S1, Supplementary Materials). Not surprisingly, 9a was not able to fit into closed conformations of InhA (pdb: 2X23; 3FNF) and did not show the expected ligand-receptor interactions. On the other hand, when an opened conformation of the InhA receptor was used (pdb: 4R9S, 4TZK, or 5G0S), we were able to identify two different binding modes for $9 \mathrm{a}$, with scores similar to the score of the co-crystalized ligands and, more importantly, with ligand-receptor interactions known to be typical for InhA inhibitors. For a detailed depiction of the predicted binding modes of $9 \mathbf{a}$ to InhA and experimental details on the computational procedures, see the Supplementary Materials.

Although the results of molecular docking are not enough to confirm the inhibition of InhA as the mechanism of the action of derivative $9 a$, we have shown that even such sterically demanding 
derivatives are able to mimic the poses and interactions of known InhA inhibitors. The selection of a suitable structure of InhA with an open conformation was crucial in this docking study.

\section{Experimental Section}

\subsection{General}

The starting 3-chloropyrazine-2-carbonitrile was purchased from Fluorochem Ltd. (Hadfield, Derbysshire, UK). Other chemicals were of a reagent or higher grade of purity and were purchased from Sigma-Aldrich (Steinheim, Germany). The progress of the reactions was monitored by Thin Layer Chromatography (TLC) (TLC Silica gel $60 \mathrm{~F}_{254}$, Merck, Darmstadt, Germany) with UV detection using wavelength of $254 \mathrm{~nm}$. Microwave-assisted reactions were performed in a CEM Discover microwave reactor with a focused field (CEM Corporation, Matthews, NC, USA) connected to an Explorer 24 autosampler (CEM Corporation), and the equipment was run under CEM's Synergy ${ }^{\mathrm{TM}}$ software (version 1.38, CEM Corporation) for setting and monitoring the conditions of the reactions. The temperature of the reaction mixture was monitored indirectly, by an internal infrared sensor. All obtained products were purified by a preparative flash chromatograph CombiFlash ${ }^{\circledR} \mathrm{Rf}$ (Teledyne Isco Inc., Lincoln, NE, USA). The type of elution was gradient, using a mixture of hexane (LachNer, Neratovice, Czech Republic) and ethyl acetate (Penta, Prague, Czech Republic) as the mobile phase. Silica gel (0.040-0.063 nm, Merck, Darmstadt, Germany) was used as the stationary phase. NMR spectra were taken with spectrometers Varian Mercury-VxBB 300, with frequencies $299.95 \mathrm{MHz}$ for ${ }^{1} \mathrm{H}$ and $75.43 \mathrm{MHz}$ for ${ }^{13} \mathrm{C}$ or Varian VNMR S500 (499.87 MHz for ${ }^{1} \mathrm{H}$ and $125.71 \mathrm{MHz}$ for $\left.{ }^{13} \mathrm{C}\right)$ (Varian Corporation, Palo Alto, CA, USA). Chemical shifts were reported in ppm $(\delta)$ and were referred indirectly to tetramethylsilane via the solvent signal. Infrared spectra were recorded with a FT-IR Nicolet 6700 spectrometer (Thermo Scientific, Waltham, MA, USA), using attenuated total reflectance (ATR) on Ge crystal. Elemental analyses were performed using a Micro Cube Elemental Analyzer (Elementar Analysensysteme $\mathrm{GmbH}$, Hanau, Germany). Melting points were assessed by SMP3 Stuart Scientific (Bibby Sterling Ltd., Staffordshire, UK) in an open capillary and are uncorrected. The lipophilicity parameters $\log P$ and $C \log P$ were calculated by software CS ChemBioDraw Ultra 14.0 (CambridgeSoft, Cambridge, MA, USA). The yields of the products refer to chromatographically pure products after all purification steps and are given in percentage to theoretical yield related to the starting acid.

\subsection{Chemistry}

\subsubsection{3-Chloropyrazine-2-carboxylic Acid (3-Cl-POA)}

The starting compound 3-chloropyrazine-2-carbonitrile $(35.8 \mathrm{mmol})$ was dispersed in a $10 \%$ solution of sodium hydroxide ( $125 \mathrm{mmol}, 3.5$ equiv.) in a round bottom flask. The reaction mixture was stirred and heated under reflux in an oil bath for $7 \mathrm{~h}$. The progress of the reaction was monitored by TLC in the system butanol/acetic acid/water (4:1:5). The reaction mixture was acidified by $10 \%$ solution of hydrochloric acid to $\mathrm{pH} 3$. Resulting crystals of 3-chloropyrazine-2-carboxylic acid were suctioned. The melting point and ${ }^{1} \mathrm{H}-\mathrm{NMR}$ corresponded with the literature [17].

\subsubsection{General Synthetic Procedure for N-Benzyl-3-chloropyrazine-2-carboxamides 1-13}

A total of $0.3 \mathrm{~g}$ of 3-Cl-POA $(1.9 \mathrm{mmol})$ was dispersed in dry toluene with thionyl chloride ( $0.4 \mathrm{~mL}, 5.7 \mathrm{mmol}, 3$ equiv.) and 1-2 drops of $N, N$-dimethylformamide (DMF) as a catalyst. The reaction mixture was stirred and heated in a round bottom flask in an oil bath under a condenser, at $95{ }^{\circ} \mathrm{C}$ for $1 \mathrm{~h}$. The solvent was evaporated in vacuo and the residue was azeotroped with dry toluene $(3 \times 20 \mathrm{~mL})$. The acyl chloride was used for the following step, without purification.

The whole amount of the 3-chloropyrazine-2-carbonyl chloride prepared in the previous step was dissolved in dry acetone. An appropriate benzylamine $(5.7 \mathrm{mmol}, 3$ equiv., with 
respect to the starting acid), along with triethylamine (1.9 mmol, 1 equiv.), were added to the reaction mixture and stirred at laboratory temperature overnight. The progress of the reaction was checked by TLC in system hexane/ethyl acetate (1:1 or 2:1). The reaction mixture was adsorbed to silica by removing the solvents in vacuo and the product was purified by flash chromatography using gradient elution with ethyl acetate in hexane. For compounds 1-3, corresponding $N$-benzyl-3-(benzylamino)pyrazine-2-carboxamides 1a-3a were formed simultaneously in a molar ratio of approximately 2:3, with an excess of $\mathbf{1 a}-\mathbf{3 a}$. $\mathrm{R}_{\mathrm{f}}$ in hexane/ethyl acetate 1:1 mobile phase: $\mathbf{1 a}-0.85, \mathbf{1}-0.49, \mathbf{2 a}-0.84, \mathbf{2}-0.51, \mathbf{3 a}-0.71$, and $\mathbf{3}-0.40$. After flash-chromatography, compounds 2, 2a, 3, 3a, 4, 8, and 13 were recrystallized from $\mathrm{EtOH} / \mathrm{H}_{2} \mathrm{O}$.

3.2.3. General Synthetic Procedure for N-Benzyl-3-(benzylamino)pyrazine-2-carboxamides (5a-7a, 9a-11a and 13a)

Compounds 5a-7a, 9a-11a, and 13a were synthetized using a microwave reactor with a focused field. Corresponding $\mathrm{N}$-benzyl-3-chloropyrazine-2-carboxamide $(0.6 \mathrm{mmol})$ was dissolved in methanol $(3 \mathrm{~mL})$ and appropriate benzylamine $(1.8 \mathrm{mmol}, 3$ equiv.), along with pyridine $(40 \mathrm{mg}, 0.6 \mathrm{mmol}$, 1 equiv.) as a base, were added. Our previous observations revealed that triethylamine (TEA) as a base cannot be used for microwave reactions. During the procedure, TEA is partially decomposed (probably to diethylamine and similar species, which may act as undesired nucleophiles in the dehalogenation reaction). The use of pyridine as the base combined with benzylamines was experimentally verified in previous projects [18]. Conditions for synthesis were $150{ }^{\circ} \mathrm{C}, 30 \mathrm{~min}$, and $100 \mathrm{~W}$. The progress of the reactions was monitored by TLC in system hexane/ethyl acetate 1:1. The reaction mixture was adsorbed on silica by removing the solvents in vacuo and the product was purified by flash chromatography using gradient elution with ethyl acetate $(0-100 \%)$ in hexane. Products $7 \mathbf{a}$ and 10a were recrystallized from $\mathrm{EtOH} / \mathrm{H}_{2} \mathrm{O}$.

\subsection{Analytical Data of Compounds}

3-Chloro-N-(2-methylbenzyl)pyrazine-2-carboxamide (1). Ochre solid. Yield 18\%; m.p. 94.5-96.5 ${ }^{\circ} \mathrm{C}$; IR (ATR-Ge, $\left.\mathrm{cm}^{-1}\right): 3292,1652(\mathrm{C}=\mathrm{O}, \mathrm{CONH}) ;{ }^{1} \mathrm{H}-\mathrm{NMR}\left(500 \mathrm{MHz}, \mathrm{CDCl}_{3}\right) \delta 8.52(\mathrm{~d}, J=2.3 \mathrm{~Hz}, 1 \mathrm{H}, \mathrm{pyr}$ ), 8.44 (d, J = 2.3 Hz, 1H, pyr.), 7.73 (bs, $1 \mathrm{H}, \mathrm{NH}), 7.34-7.17(\mathrm{~m}, 4 \mathrm{H}, \mathrm{Ar}), 4.65\left(\mathrm{~d}, J=5.7 \mathrm{~Hz}, 2 \mathrm{H}, \mathrm{CH}_{2}\right), 2.39$ $\left(\mathrm{s}, 3 \mathrm{H}, \mathrm{CH}_{3}\right) ;{ }^{13} \mathrm{C}-\mathrm{NMR}\left(126 \mathrm{MHz}, \mathrm{CDCl}_{3}\right) \delta 161.67,148.25,145.62,143.10,140.51,136.48,135.17,130.54$, 128.65, 127.91, 126.22, 41.89, 19.04; Elemental analysis: calc. for $\mathrm{C}_{13} \mathrm{H}_{12} \mathrm{ClN}_{3} \mathrm{O}$ (MW 261.71): 59.66\% C, $4.62 \% \mathrm{H}, 16.06 \% \mathrm{~N}$; found $59.69 \% \mathrm{C}, 4.91 \% \mathrm{H}, 15.85 \% \mathrm{~N}$.

N-(2-Methylbenzyl)-3-((2-methylbenzyl)amino)pyrazine-2-carboxamide (1a). Yellow-brown solid. Yield 26\%; m.p. 89.6-91.4 ${ }^{\circ} \mathrm{C}$; IR (ATR-Ge, cm ${ }^{-1}$ ): 3395, 3321, 1659 (C=O, CONH); ${ }^{1} \mathrm{H}-\mathrm{NMR}\left(500 \mathrm{MHz}, \mathrm{CDCl}_{3}\right) \delta$ 8.96 (bs, $1 \mathrm{H}, \mathrm{NH}), 8.21$ (d, $J=2.4 \mathrm{~Hz}, 1 \mathrm{H}$, pyr.), $8.13(\mathrm{t}, J=5.8 \mathrm{~Hz}, 1 \mathrm{H}, \mathrm{NH}), 7.67$ (d, $J=2.4 \mathrm{~Hz}, 1 \mathrm{H}$, pyr.), 7.39-7.16 (m, 8H, Ar), $4.71\left(\mathrm{~d}, J=5.5 \mathrm{~Hz}, 2 \mathrm{H}, \mathrm{CH}_{2}\right), 4.60\left(\mathrm{~d}, J=5.8 \mathrm{~Hz}, 2 \mathrm{H}, \mathrm{CH}_{2}\right), 2.40(\mathrm{~d}, J=17.6 \mathrm{~Hz}$, $6 \mathrm{H}, \mathrm{CH}_{3} ;{ }^{13} \mathrm{C}-\mathrm{NMR}\left(126 \mathrm{MHz}, \mathrm{CDCl}_{3}\right) \delta 166.21,154.53,146.49,136.47,136.32,136.22,135.54,130.49$, 130.32, 129.52, 128.26, 128.04, 127.73, 127.28, 126.42, 126.20, 126.02, 42.51, 41.30, 19.11, 19.03; Elemental analysis: calc. for $\mathrm{C}_{21} \mathrm{H}_{22} \mathrm{~N}_{4} \mathrm{O}$ (MW 346.43): $72.81 \% \mathrm{C}, 6.40 \% \mathrm{H}, 16.17 \% \mathrm{~N}$; found $72.44 \% \mathrm{C}, 6.49 \% \mathrm{H}$, $16.35 \% \mathrm{~N}$.

3-Chloro-N-(4-methylbenzyl)pyrazine-2-carboxamide (2). Pale brown solid. Yield 17\%; m.p. 126.2-129.1 ${ }^{\circ} \mathrm{C}$; IR (ATR-Ge, $\left.\mathrm{cm}^{-1}\right): 3303,1655(\mathrm{C}=\mathrm{O}, \mathrm{CONH}) ;{ }^{1} \mathrm{H}-\mathrm{NMR}\left(500 \mathrm{MHz}, \mathrm{CDCl}_{3}\right) \delta 8.52(\mathrm{~d}, J=2.3 \mathrm{~Hz}, 1 \mathrm{H}$, pyr.), 8.45 (d, $J=2.3 \mathrm{~Hz}, 1 \mathrm{H}$, pyr.), 7.86 (bs, $1 \mathrm{H}, \mathrm{NH}), 7.30-7.24(\mathrm{~m}, 2 \mathrm{H}, \mathrm{Ar}), 7.21-7.13(\mathrm{~m}, 2 \mathrm{H}, \mathrm{Ar}), 4.61$ $\left(\mathrm{d}, J=5.9 \mathrm{~Hz}, 2 \mathrm{H}, \mathrm{CH}_{2}, 2.35\left(\mathrm{~s}, 3 \mathrm{H}, \mathrm{CH}_{3}\right) ;{ }^{13} \mathrm{C}-\mathrm{NMR}\left(126 \mathrm{MHz}, \mathrm{CDCl}_{3}\right) \delta\right.$ 161.77, 148.37, 145.63, 143.12, $140.49,137.43,134.53,129.42,127.94,43.54,21.07$; Elemental analysis: calc. for $\mathrm{C}_{13} \mathrm{H}_{12} \mathrm{ClN}_{3} \mathrm{O}$ (MW 261.71): $59.66 \% \mathrm{C}, 4.62 \% \mathrm{H}, 16.06 \% \mathrm{~N}$; found $59.47 \% \mathrm{C}, 5.07 \% \mathrm{H}, 15.69 \% \mathrm{~N}$.

$\mathrm{N}$-(4-Methylbenzyl)-3-((4-methylbenzyl)amino)pyrazine-2-carboxamide (2a). Pale yellow solid. Yield 25\%; m.p. $145.8-147.6{ }^{\circ} \mathrm{C}$; IR (ATR-Ge, cm ${ }^{-1}$ ): 3373, 3344, 1650 (C=O, CONH); ${ }^{1} \mathrm{H}-\mathrm{NMR}\left(300 \mathrm{MHz}, \mathrm{CDCl}_{3}\right)$ $\delta 9.03(\mathrm{t}, J=5.7 \mathrm{~Hz}, 1 \mathrm{H}, \mathrm{NH}), 8.22(\mathrm{~s}, 1 \mathrm{H}, \mathrm{NH}), 8.18(\mathrm{~d}, J=2.4 \mathrm{~Hz}, 1 \mathrm{H}$, pyr. $), 7.64(\mathrm{~d}, J=2.4 \mathrm{~Hz}, 1 \mathrm{H}$, 
pyr.), 7.30-7.21 (m, 4H, Ar), 7.18-7.12 (m, 4H, Ar), $4.67\left(\mathrm{~d}, J=5.7 \mathrm{~Hz}, 2 \mathrm{H}, \mathrm{CH}_{2}\right), 4.55(\mathrm{~d}, J=6.0 \mathrm{~Hz}, 2 \mathrm{H}$, $\left.\mathrm{CH}_{2}\right), 2.34\left(\mathrm{~d}, J=2.9 \mathrm{~Hz}, 6 \mathrm{H}, \mathrm{CH}_{3}\right) ;{ }^{13} \mathrm{C}-\mathrm{NMR}\left(75 \mathrm{MHz} \mathrm{CDCl}_{3}\right) \delta 166.28,154.52,146.45,137.17,136.66$, 135.80, 134.93, 129.52, 129.35, 129.19, 127.68, 127.49, 126.46, 44.10, 42.89, 21.07; Elemental analysis: calc. for $\mathrm{C}_{21} \mathrm{H}_{22} \mathrm{~N}_{4} \mathrm{O}$ (MW 346.43): $72.81 \%$ C, $6.40 \% \mathrm{H}, 16.17 \% \mathrm{~N}$; found $72.47 \% \mathrm{C}, 6.40 \% \mathrm{H}, 15.73 \% \mathrm{~N}$.

3-Chloro-N-(4-methoxybenzyl)pyrazine-2-carboxamide (3). Brown solid. Yield 11\%; m.p. 107.7-109.3 ${ }^{\circ} \mathrm{C}$; IR (ATR-Ge, cm ${ }^{-1}$ ): 3276, 1648 (C=O, CONH); ${ }^{1} \mathrm{H}-\mathrm{NMR}\left(300 \mathrm{MHz}, \mathrm{CDCl}_{3}\right) \delta 8.51$ (d, $J=2.3 \mathrm{~Hz}, 1 \mathrm{H}$, pyr.), $8.43(\mathrm{~d}, J=2.3 \mathrm{~Hz}, 1 \mathrm{H}$, pyr.), $7.82(\mathrm{bs}, 1 \mathrm{H}, \mathrm{NH}), 7.32-7.24(\mathrm{~m}, 2 \mathrm{H}, \mathrm{Ar}), 6.91-6.84(\mathrm{~m}, 2 \mathrm{H}, \mathrm{Ar}), 4.58(\mathrm{~d}, J=$ $\left.5.8 \mathrm{~Hz}, 2 \mathrm{H}, \mathrm{CH}_{2}\right), 3.79\left(\mathrm{~s}, 3 \mathrm{H}, \mathrm{CH}_{3}\right) ;{ }^{13} \mathrm{C}-\mathrm{NMR}\left(75 \mathrm{MHz} \mathrm{CDCl}_{3}\right) \delta 161.76,159.16,148.37,145.65,143.14$, 140.51, 129.65, 129.34, 114.15, 55.28, 43.26.; Elemental analysis: calc. for $\mathrm{C}_{13} \mathrm{H}_{12} \mathrm{ClN}_{3} \mathrm{O}_{2}$ (MW 277.71): $56.23 \% \mathrm{C}, 4.36 \% \mathrm{H}, 15.13 \% \mathrm{~N}$; found $56.64 \% \mathrm{C}, 4.84 \% \mathrm{H}, 14.82 \% \mathrm{~N}$.

N-(4-Methoxybenzyl)-3-((4-methoxybenzyl)amino)pyrazine-2-carboxamide (3a). Yellow-brown solid. Yield 15\%; m.p. 83.1-85.7 ${ }^{\circ} \mathrm{C}$; IR (ATR-Ge, $\left.\mathrm{cm}^{-1}\right)$ : 3392, 3335, 1652 (C=O, CONH); ${ }^{1} \mathrm{H}-\mathrm{NMR}(300 \mathrm{MHz}$, $\left.\mathrm{CDCl}_{3}\right) \delta 8.99$ (bs, $\left.1 \mathrm{H}, \mathrm{NH}\right), 8.19$ (bs, $\left.1 \mathrm{H}, \mathrm{NH}\right), 8.17$ (d, $J=2.4 \mathrm{~Hz}, 1 \mathrm{H}$, pyr.), 7.64 (d, J = 2.4 Hz, $1 \mathrm{H}$, pyr.), 7.34-7.22 (m, 4H, Ar), 6.91-6.82 (m, 4H, Ar), $4.63\left(\mathrm{~d}, J=5.6 \mathrm{~Hz}, 2 \mathrm{H}, \mathrm{CH}_{2}\right), 4.51\left(\mathrm{~d}, J=5.9 \mathrm{~Hz}, 2 \mathrm{H}, \mathrm{CH}_{2}\right)$, $3.79\left(\mathrm{~s}, 6 \mathrm{H}, \mathrm{CH}_{3}\right) ;{ }^{13} \mathrm{C}-\mathrm{NMR}\left(75 \mathrm{MHz}, \mathrm{CDCl}_{3}\right) \delta 166.28,159.03,158.76,154.52,146.46,131.00,130.09$, 129.55, 129.06, 129.06, 128.87, 126.51, 114.11, 113.97, 55.28, 43.86, 42.63; Elemental analysis: calc. for $\mathrm{C}_{21} \mathrm{H}_{22} \mathrm{~N}_{4} \mathrm{O}_{3}$ (MW 378.43): 66.65\% C, 5.86\% H, $14.81 \% \mathrm{~N}$; found $66.95 \% \mathrm{C}, 6.12 \% \mathrm{H}, 14.35 \% \mathrm{~N}$.

3-Chloro-N-(2,4-dimethoxybenzyl)pyrazine-2-carboxamide (4). Pale brown solid. Yield 14\%; m.p. 115.2-117. ${ }^{\circ} \mathrm{C}$; IR (ATR-Ge, cm $\left.{ }^{-1}\right): 3275,1640(\mathrm{C}=\mathrm{O}, \mathrm{CONH}) ;{ }^{1} \mathrm{H}-\mathrm{NMR}(300 \mathrm{MHz}, \mathrm{DMSO}) \delta 8.97(\mathrm{t}$, $J=5.7 \mathrm{~Hz}, 1 \mathrm{H}, \mathrm{NH}), 8.68(\mathrm{~d}, J=2.5 \mathrm{~Hz}, 1 \mathrm{H}$, pyr. $), 8.61(\mathrm{~d}, J=2.5 \mathrm{~Hz}, 1 \mathrm{H}$, pyr.), $7.19(\mathrm{~d}, J=8.3 \mathrm{~Hz}, 1 \mathrm{H}$, $\mathrm{Ar}), 6.58-6.47(\mathrm{~m}, 2 \mathrm{H}, \mathrm{Ar}), 4.37\left(\mathrm{~d}, J=5.8 \mathrm{~Hz}, 2 \mathrm{H}, \mathrm{CH}_{2}\right), 3.79\left(\mathrm{~s}, 3 \mathrm{H}, \mathrm{CH}_{3}\right), 3.74\left(\mathrm{~s}, 3 \mathrm{H}, \mathrm{CH}_{3}\right) ;{ }^{13} \mathrm{C}-\mathrm{NMR}$ (75 MHz, DMSO) $\delta 163.74,160.09,157.95,148.54,145.32,145.16,142.61,129.04,118.24,104.54,98.46$, 55.63, 55.40, 37.43.; Elemental analysis: calc. for $\mathrm{C}_{14} \mathrm{H}_{14} \mathrm{ClN}_{3} \mathrm{O}_{3}$ (MW 307.73): 54.64\% C, $4.59 \% \mathrm{H}$, $13.65 \% \mathrm{~N}$; found $54.95 \% \mathrm{C}, 4.96 \% \mathrm{H}, 13.66 \% \mathrm{~N}$.

3-Chloro-N-(2-chlorobenzyl)pyrazine-2-carboxamide (5). Pale brown solid. Yield 46\%; m.p. 101.7-102.8 ${ }^{\circ} \mathrm{C}$; IR (ATR-Ge, cm $\left.{ }^{-1}\right): 3362,1672(\mathrm{C}=\mathrm{O}, \mathrm{CONH}){ }^{1} \mathrm{H}-\mathrm{NMR}\left(500 \mathrm{MHz}, \mathrm{CDCl}_{3}\right) \delta 8.53(\mathrm{~d}, J=2.3 \mathrm{~Hz}, 1 \mathrm{H}$, pyr.), $8.48(\mathrm{~d}, J=2.3 \mathrm{~Hz}, 1 \mathrm{H}$, pyr.), 8.10 (bs, $1 \mathrm{H}, \mathrm{NH}), 7.51-7.46(\mathrm{~m}, 1 \mathrm{H}, \mathrm{Ar}), 7.41-7.37(\mathrm{~m}, 1 \mathrm{H}, \mathrm{Ar})$, 7.28-7.23 (m, 2H, Ar), $4.74\left(\mathrm{~d}, J=6.3 \mathrm{~Hz}, 2 \mathrm{H}, \mathrm{CH}_{2}\right) ;{ }^{13} \mathrm{C}-\mathrm{NMR}\left(126 \mathrm{MHz}, \mathrm{CDCl}_{3}\right) \delta 161.84,148.37$, 145.74, 142.83, 140.55, 135.03, 133.73, 130.39, 129.54, 129.13, 127.14, 41.67; Elemental analysis: calc. for $\mathrm{C}_{12} \mathrm{H}_{9} \mathrm{Cl}_{2} \mathrm{~N}_{3} \mathrm{O}$ (MW 282.12): $51.09 \% \mathrm{C}, 3.22 \% \mathrm{H}, 14.89 \% \mathrm{~N}$; found $50.85 \% \mathrm{C}, 3.58 \% \mathrm{H}, 14.53 \% \mathrm{~N}$.

3-Chloro-N-(3-chlorobenzyl)pyrazine-2-carboxamide (6). Brown solid. Yield 56\%; m.p. 92.5-95.0 ${ }^{\circ} \mathrm{C}$; IR (ATR-Ge, cm $\left.{ }^{-1}\right)$ : 3279, 1660 (C=O, CONH); ${ }^{1} \mathrm{H}-\mathrm{NMR}\left(500 \mathrm{MHz}, \mathrm{CDCl}_{3}\right) \delta 8.54(\mathrm{~d}, \mathrm{~J}=2.3 \mathrm{~Hz}, 1 \mathrm{H}$, pyr.), $8.47(\mathrm{~d}, J=2.3 \mathrm{~Hz}, 1 \mathrm{H}, \mathrm{pyr}$ ), 8.01 (bs, $1 \mathrm{H}, \mathrm{NH}), 7.34(\mathrm{~d}, J=2.0 \mathrm{~Hz}, 1 \mathrm{H}, \mathrm{Ar}), 7.31-7.22(\mathrm{~m}, 3 \mathrm{H}, \mathrm{Ar}), 4.62$ $\left(\mathrm{d}, \mathrm{J}=6.1 \mathrm{~Hz}, 2 \mathrm{H}, \mathrm{CH}_{2}\right) ;{ }^{13} \mathrm{C}-\mathrm{NMR}\left(126 \mathrm{MHz}, \mathrm{CDCl}_{3}\right) \delta 161.92,148.40,145.83,142.74,140.54,139.66$, 134.53, 130.00, 127.82, 127.80, 125.94, 43.07; Elemental analysis: calc. for $\mathrm{C}_{12} \mathrm{H}_{9} \mathrm{Cl}_{2} \mathrm{~N}_{3} \mathrm{O}$ (MW 282.12): $51.09 \% \mathrm{C}, 3.22 \% \mathrm{H}, 14.89 \% \mathrm{~N}$; found $51.42 \% \mathrm{C}, 3.69 \% \mathrm{H}, 14.61 \% \mathrm{~N}$.

3-Chloro-N-(4-chlorobenzyl)pyrazine-2-carboxamide (7). Brown solid. Yield 63\%; m.p. $133.5-135.2^{\circ} \mathrm{C}$; IR (ATR-Ge, $\left.\mathrm{cm}^{-1}\right): 3382,1669$ (C=O, CONH); ${ }^{1} \mathrm{H}-\mathrm{NMR}\left(300 \mathrm{MHz}, \mathrm{CDCl}_{3}\right) \delta 8.53(\mathrm{~d}, J=2.4 \mathrm{~Hz}, 1 \mathrm{H}$, pyr.), 8.45 (d, $J=2.3 \mathrm{~Hz}, 1 \mathrm{H}$, pyr.), 7.94 (bs, $1 \mathrm{H}, \mathrm{NH}), 7.34-7.24(\mathrm{~m}, 4 \mathrm{H}, \mathrm{Ar}), 4.61\left(\mathrm{~d}, J=6.1 \mathrm{~Hz}, 2 \mathrm{H}, \mathrm{CH}_{2}\right)$; ${ }^{13} \mathrm{C}-\mathrm{NMR}\left(75 \mathrm{MHz}, \mathrm{CDCl}_{3}\right) \delta 161.90,148.42,145.81,142.80,140.52,136.15,133.48,129.22,128.87,43.01$; Elemental analysis: calc. for $\mathrm{C}_{12} \mathrm{H}_{9} \mathrm{Cl}_{2} \mathrm{~N}_{3} \mathrm{O}$ (MW 282.12): $51.09 \% \mathrm{C}, 3.22 \% \mathrm{H}, 14.89 \% \mathrm{~N}$; found $50.81 \%$ C, $3.50 \% \mathrm{H}, 14.74 \% \mathrm{~N}$.

3-Chloro-N-(2,4-dichlorobenzyl)pyrazine-2-carboxamide (8). Ochre solid. Yield 58\%; m.p. 99.5-100.4 ${ }^{\circ} \mathrm{C}$; IR (ATR-Ge, $\mathrm{cm}^{-1}$ ): 3295, 1655 (C=O, CONH); ${ }^{1} \mathrm{H}-\mathrm{NMR}(300 \mathrm{MHz}, \mathrm{DMSO}) \delta 9.38(\mathrm{t}, J=6.0 \mathrm{~Hz}, 1 \mathrm{H}, \mathrm{NH})$, 8.73 (d, J = 2.5 Hz, $1 \mathrm{H}$, pyr.), 8.66 (d, $J=2.4 \mathrm{~Hz}, 1 \mathrm{H}$, pyr.), $7.63(\mathrm{t}, J=1.2 \mathrm{~Hz}, 1 \mathrm{H}, \mathrm{Ar}), 7.46(\mathrm{~d}, J=1.3 \mathrm{~Hz}$, $2 \mathrm{H}, \mathrm{Ar}), 4.53\left(\mathrm{~d}, J=5.9 \mathrm{~Hz}, 2 \mathrm{H}, \mathrm{CH}_{2}\right) ;{ }^{13} \mathrm{C}-\mathrm{NMR}(75 \mathrm{MHz}, \mathrm{DMSO}) \delta 163.93,147.60,145.72,145.33$, 
$142.63,134.94,133.25,132.69,130.38,128.85,127.59,40.53$; Elemental analysis: calc. for $\mathrm{C}_{12} \mathrm{H}_{8} \mathrm{Cl}_{3} \mathrm{~N}_{3} \mathrm{O}$ (MW 316.57): $45.53 \%$ C, $2.55 \% \mathrm{H}, 13.27 \% \mathrm{~N}$; found $45.72 \% \mathrm{C}, 2.79 \% \mathrm{H}, 12.96 \% \mathrm{~N}$.

3-Chloro-N-(3,4-dichlorobenzyl)pyrazine-2-carboxamide (9). Brown solid. Yield 49\%; m.p. 121.5-124.5 ${ }^{\circ} \mathrm{C}$; IR (ATR-Ge, cm $\left.{ }^{-1}\right)$ : 3241, $1648(\mathrm{C}=\mathrm{O}, \mathrm{CONH}) ;{ }^{1} \mathrm{H}-\mathrm{NMR}\left(300 \mathrm{MHz}, \mathrm{CDCl}_{3}\right) \delta 8.55(\mathrm{~d}, J=2.3 \mathrm{~Hz}, 1 \mathrm{H}$, pyr.), 8.47 (d, $J=2.3 \mathrm{~Hz}, 1 \mathrm{H}$, pyr.), 8.02 (bs, $1 \mathrm{H}, \mathrm{NH}), 7.47-7.36(\mathrm{~m}, 2 \mathrm{H}, \mathrm{Ar}), 7.28-7.16(\mathrm{~m}, 1 \mathrm{H}, \mathrm{Ar}), 4.59$ $\left(\mathrm{d}, J=6.1 \mathrm{~Hz}, 2 \mathrm{H}, \mathrm{CH}_{2}\right) ;{ }^{13} \mathrm{C}-\mathrm{NMR}\left(75 \mathrm{MHz}, \mathrm{CDCl}_{3}\right) \delta 161.96,148.48,145.97,142.51,140.54,137.96$, $132.73,131.69,130.67,129.67,127.16,42.54$; Elemental analysis: calc. for $\mathrm{C}_{12} \mathrm{H}_{8} \mathrm{Cl}_{3} \mathrm{~N}_{3} \mathrm{O}$ (MW 316.57): $45.53 \%$ C, $2.55 \% \mathrm{H}, 13.27 \% \mathrm{~N}$; found $45.41 \% \mathrm{C}, 2.77 \% \mathrm{H}, 12.87 \% \mathrm{~N}$.

3-Chloro-N-(2-fluorobenzyl)pyrazine-2-carboxamide (10). Pale brown solid. Yield 46\%; m.p. 116.7-117.9 ${ }^{\circ} \mathrm{C}$; IR (ATR-Ge, $\left.\mathrm{cm}^{-1}\right)$ : 3320, $1661(\mathrm{C}=\mathrm{O}, \mathrm{CONH}) ;{ }^{1} \mathrm{H}-\mathrm{NMR}\left(500 \mathrm{MHz}, \mathrm{CDCl}_{3}\right) \delta 8.53(\mathrm{~d}, J=2.2 \mathrm{~Hz}, 1 \mathrm{H}$, pyr.), 8.47 (d, $J=2.2 \mathrm{~Hz}, 1 \mathrm{H}$, pyr.), 8.01 (bs, $1 \mathrm{H}, \mathrm{NH}), 7.44$ (dt, $J=7.6 \mathrm{~Hz} J=2.0 \mathrm{~Hz}, 1 \mathrm{H}, \mathrm{Ar}), 7.32-7.26$ (m, 1H, Ar), 7.15-7.10 (m, 1H, Ar), 7.10-7.05 (m, 1H, Ar), $4.70\left(\mathrm{~d}, J=5.9 \mathrm{~Hz}, 2 \mathrm{H}, \mathrm{CH}_{2}\right) ;{ }^{13} \mathrm{C}-\mathrm{NMR}$ $\left(125 \mathrm{MHz}, \mathrm{CDCl}_{3}\right) \delta 161.9,161.1(\mathrm{~d}, J=247.1 \mathrm{~Hz}), 148.4,145.8,142.9,140.5,130.4(\mathrm{~d}, J=3.9 \mathrm{~Hz}), 129.5$ $(\mathrm{d}, J=7.7 \mathrm{~Hz}), 124.6(\mathrm{~d}, J=15.3 \mathrm{~Hz}), 124.4(\mathrm{~d}, J=3.9 \mathrm{~Hz}), 115.4(\mathrm{~d}, J=21.0 \mathrm{~Hz}), 37.7(\mathrm{~d}, J=3.9 \mathrm{~Hz})$; Elemental analysis: calc. for $\mathrm{C}_{12} \mathrm{H}_{9} \mathrm{ClFN}_{3} \mathrm{O}$ (MW 265.67): $54.25 \% \mathrm{C}, 3.41 \% \mathrm{H}, 15.82 \% \mathrm{~N}$; found $54.61 \%$ C, $3.89 \% \mathrm{H}, 15.59 \% \mathrm{~N}$.

3-Chloro-N-(4-fluorobenzyl)pyrazine-2-carboxamide (11). Brown solid. Yield 55\%; m.p. 115.0-117.9 ${ }^{\circ} \mathrm{C}$; IR (ATR-Ge, $\left.\mathrm{cm}^{-1}\right)$ : 3403, 1661 (C=O, CONH); ${ }^{1} \mathrm{H}-\mathrm{NMR}\left(300 \mathrm{MHz}, \mathrm{CDCl}_{3}\right) \delta 8.53-8.51$ (m, 1H, pyr.), $8.45(\mathrm{~d}, J=2.4 \mathrm{~Hz}, 1 \mathrm{H}, \mathrm{pyr}$ ), $7.92(\mathrm{bs}, 1 \mathrm{H}, \mathrm{NH}), 7.37-7.28(\mathrm{~m}, 2 \mathrm{H}, \mathrm{Ar}), 7.07-6.97$ (m, 2H, Ar), 4.60 (d, $\left.J=6.5 \mathrm{~Hz}, 2 \mathrm{H}, \mathrm{CH}_{2}\right) ;{ }^{13} \mathrm{C}-\mathrm{NMR}\left(75 \mathrm{MHz}, \mathrm{CDCl}_{3}\right) \delta 162.2(\mathrm{~d}, J=243.1 \mathrm{~Hz}), 161.9,148.4,145.9,142.9$, 140.6, $133.4(\mathrm{~d}, J=3.5 \mathrm{~Hz}), 129.6(\mathrm{~d}, J=9.2 \mathrm{~Hz}), 115.6(\mathrm{~d}, J=21.9 \mathrm{~Hz}), 43.0$; Elemental analysis: calc. for $\mathrm{C}_{12} \mathrm{H}_{9} \mathrm{ClFN}_{3} \mathrm{O}$ (MW 265.67): $54.25 \% \mathrm{C}, 3.41 \% \mathrm{H}, 15.82 \% \mathrm{~N}$; found $54.71 \% \mathrm{C}, 3.76 \% \mathrm{H}, 15.78 \% \mathrm{~N}$.

3-Chloro-N-(3-(trifluoromethyl)benzyl)pyrazine-2-carboxamide (12). Pale yellow solid. Yield 55\%; m.p. 79.2-81.5 ${ }^{\circ} \mathrm{C}$; IR (ATR-Ge, cm ${ }^{-1}$ ): 3292, 1662 (C=O, CONH); ${ }^{1} \mathrm{H}-\mathrm{NMR}(500 \mathrm{MHz}, \mathrm{DMSO}) \delta 9.44(\mathrm{t}$, $J=6.0 \mathrm{~Hz}, 1 \mathrm{H}, \mathrm{NH}), 8.72(\mathrm{~d}, J=2.4 \mathrm{~Hz}, 1 \mathrm{H}$, pyr.), 8.65 (d, $J=2.4 \mathrm{~Hz}, 1 \mathrm{H}$, pyr.), $7.74-7.72(1 \mathrm{H}, \mathrm{m}, \mathrm{Ar})$, 7.68-7.57 (m, 3H, Ar), $4.60\left(\mathrm{~d}, J=6.0 \mathrm{~Hz}, 2 \mathrm{H}, \mathrm{CH}_{2}\right) ;{ }^{13} \mathrm{C}-\mathrm{NMR}(125 \mathrm{MHz}, \mathrm{DMSO}) \delta 164.0,147.9,145.7$, 145.3, 142.7, 140.4, 131.6, 129.6, $129.3(\mathrm{q}, J=31.4 \mathrm{~Hz}), 124.4(\mathrm{q}, J=272.5 \mathrm{~Hz}), 123.9$ (q, $J=3.8 \mathrm{~Hz}), 42.0$; Elemental analysis: calc. for $\mathrm{C}_{13} \mathrm{H}_{9} \mathrm{ClF}_{3} \mathrm{~N}_{3} \mathrm{O}$ (MW 315.68): $49.46 \% \mathrm{C}, 2.87 \% \mathrm{H}, 13.31 \% \mathrm{~N}$; found $49.12 \%$ C, $3.17 \% \mathrm{H}, 12.89 \% \mathrm{~N}$.

3-Chloro-N-(4-(trifluoromethyl)benzyl)pyrazine-2-carboxamide (13). White solid. Yield 67\%; m.p. 123.7-125.7 ${ }^{\circ} \mathrm{C}$; IR (ATR-Ge, cm $\left.{ }^{-1}\right): 3299,1660(\mathrm{C}=\mathrm{O}, \mathrm{CONH}) ;{ }^{1} \mathrm{H}-\mathrm{NMR}\left(500 \mathrm{MHz}, \mathrm{CDCl}_{3}\right) \delta 8.54(\mathrm{~d}$, $J=2.4 \mathrm{~Hz}, 1 \mathrm{H}$, pyr.), 8.46 (d, $J=2.4 \mathrm{~Hz}, 1 \mathrm{H}$, pyr.), 8.05 (bs, 1H, NH), 7.62-7.57 (m, 2H, Ar), 7.50-7.45 (m, 2H, AA', BB', Ar), $4.70\left(\mathrm{~d}, 2 \mathrm{H}, J=6.4 \mathrm{~Hz}, \mathrm{CH}_{2}\right) ;{ }^{13} \mathrm{C}-\mathrm{NMR}\left(125 \mathrm{MHz}, \mathrm{CDCl}_{3}\right) \delta 162.1,148.5,145.9,142.7$, 141.7, 140.6, $129.9(\mathrm{q}, J=32.4 \mathrm{~Hz}), 128.0,125.7(\mathrm{q}, J=3.9 \mathrm{~Hz}), 124.0(\mathrm{q}, J=271.9 \mathrm{~Hz}), 43.2$; Elemental analysis: calc. for $\mathrm{C}_{13} \mathrm{H}_{9} \mathrm{ClF}_{3} \mathrm{~N}_{3} \mathrm{O}$ (MW 315.68): $49.46 \% \mathrm{C}, 2.87 \% \mathrm{H}, 13.31 \% \mathrm{~N}$; found $49.01 \% \mathrm{C}, 3.34 \%$ $\mathrm{H}, 12.95 \% \mathrm{~N}$.

N-(2-Chlorobenzyl)-3-((2-chlorobenzyl)amino)pyrazine-2-carboxamide (5a). White solid. Yield 39\%; m.p. 90.8-91.9 ${ }^{\circ} \mathrm{C}$; IR (ATR-Ge, cm ${ }^{-1}$ ): 3382, 3353, 1663 (C=O, CONH); ${ }^{1} \mathrm{H}-\mathrm{NMR}\left(500 \mathrm{MHz}, \mathrm{CDCl}_{3}\right) \delta 9.09$ (bs, $1 \mathrm{H}, \mathrm{NH}), 8.39(\mathrm{t}, J=6.1 \mathrm{~Hz}, 1 \mathrm{H}, \mathrm{NH}), 8.19(\mathrm{~d}, J=2.4 \mathrm{~Hz}, 1 \mathrm{H}$, pyr.), $7.71(\mathrm{~d}, J=2.4 \mathrm{~Hz}, 1 \mathrm{H}$, pyr.), 7.45-7.36 (m, 4H, Ar), 7.28-7.23 (m, 2H, Ar), 7.23-7.18 (m, 2H, Ar), $4.82\left(\mathrm{~d}, J=6.1 \mathrm{~Hz}, 2 \mathrm{H}, \mathrm{CH}_{2}\right), 4.72(\mathrm{~d}$, $\left.J=6.3 \mathrm{~Hz}, 2 \mathrm{H}, \mathrm{CH}_{2}\right) ;{ }^{13} \mathrm{C}-\mathrm{NMR}\left(126 \mathrm{MHz}, \mathrm{CDCl}_{3}\right) \delta 166.40,154.52,146.50,136.27,135.40,133.64,133.57$, 129.96, 129.70, 129.58, 129.45, 129.17, 128.90, 128.35, 127.06, 126.73, 126.46, 42.12, 41.04; Elemental analysis: calc. for $\mathrm{C}_{19} \mathrm{H}_{16} \mathrm{Cl}_{2} \mathrm{~N}_{4} \mathrm{O}$ (MW 387.26): $58.93 \% \mathrm{C}, 4.16 \% \mathrm{H}, 14.47 \% \mathrm{~N}$; found $58.69 \% \mathrm{C}, 4.07 \%$ $\mathrm{H}, 14.21 \% \mathrm{~N}$.

N-(3-Chlorobenzyl)-3-((3-chlorobenzyl)amino)pyrazine-2-carboxamide (6a). Yellow solid. Yield 62\%; m.p. 68.7-70.4 ${ }^{\circ} \mathrm{C}$; IR (ATR-Ge, $\mathrm{cm}^{-1}$ ): 3377, 3337, $1652(\mathrm{C}=\mathrm{O}, \mathrm{CONH}) ;{ }^{1} \mathrm{H}-\mathrm{NMR}\left(500 \mathrm{MHz}, \mathrm{CDCl}_{3}\right) \delta 9.04$ $(\mathrm{t}, J=6.3 \mathrm{~Hz}, 1 \mathrm{H}, \mathrm{NH}), 8.32$ (bs, $1 \mathrm{H}, \mathrm{NH}), 8.20$ (d, $J=2.4 \mathrm{~Hz}, 1 \mathrm{H}$, pyr.), 7.71 (d, $J=2.4 \mathrm{~Hz}, 1 \mathrm{H}$, pyr.), 
7.37-7.33 (m, 2H, Ar), 7.31-7.21 (m, 6H, Ar), $4.71\left(\mathrm{~d}, J=6.0 \mathrm{~Hz}, 2 \mathrm{H}, \mathrm{CH}_{2}\right), 4.58(\mathrm{~d}, J=6.3 \mathrm{~Hz}, 2 \mathrm{H}$, $\left.\mathrm{CH}_{2}\right) ;{ }^{13} \mathrm{C}-\mathrm{NMR}\left(126 \mathrm{MHz}, \mathrm{CDCl}_{3}\right) \delta 166.45,154.46,146.66,141.14,140.07,134.57,134.34,130.09,129.98$, 129.76, 127.69, 127.65, 127.56, 127.24, 126.25, 125.70, 125.53, 43.73, 42.55; Elemental analysis: calc. for $\mathrm{C}_{19} \mathrm{H}_{16} \mathrm{Cl}_{2} \mathrm{~N}_{4} \mathrm{O}$ (MW 387.26): $58.93 \%$ C, $4.16 \% \mathrm{H}, 14.47 \% \mathrm{~N}$; found $59.16 \% \mathrm{C}, 4.17 \% \mathrm{H}, 14.20 \% \mathrm{~N}$.

$\mathrm{N}$-(4-Chlorobenzyl)-3-((4-chlorobenzyl)amino)pyrazine-2-carboxamide (7a). Pale yellow solid. Yield 77\%; m.p. 150.1-151.4 ${ }^{\circ} \mathrm{C}$; IR (ATR-Ge, $\left.\mathrm{cm}^{-1}\right)$ : 3375, 3346, 1651 (C=O, CONH); ${ }^{1} \mathrm{H}-\mathrm{NMR}\left(300 \mathrm{MHz}, \mathrm{CDCl}_{3}\right)$ $\delta 8.94$ (bs, $1 \mathrm{H}, \mathrm{NH}), 8.20$ (bs, $1 \mathrm{H}, \mathrm{NH}), 8.10$ (s, 1H, pyr.), 7.60 (s, 1H, pyr.), 7.32-7.12 (m, 8H, Ar), 4.59 $\left(\mathrm{d}, J=5.9 \mathrm{~Hz}, 2 \mathrm{H}, \mathrm{CH}_{2}\right), 4.47\left(\mathrm{~d}, J=5.9 \mathrm{~Hz}, 2 \mathrm{H}, \mathrm{CH}_{2}\right) ;{ }^{13} \mathrm{C}-\mathrm{NMR}\left(75 \mathrm{MHz}, \mathrm{CDCl}_{3}\right) \delta 166.4,154.5$, 146.6, 137.5, 136.5, 133.3, 132.8, 130.0, 129.0, 128.8, 128.6, 126.3, 43.6, 42.4; Elemental analysis: calc. for $\mathrm{C}_{19} \mathrm{H}_{16} \mathrm{Cl}_{2} \mathrm{~N}_{4} \mathrm{O}$ (MW 387.26): $58.93 \%$ C, $4.16 \% \mathrm{H}, 14.47 \% \mathrm{~N}$; found $58.68 \% \mathrm{C}, 4.24 \% \mathrm{H}, 14.16 \% \mathrm{~N}$.

N-(3,4-Dichlorobenzyl)-3-((3,4-dichlorobenzyl)amino)pyrazine-2-carboxamide (9a). Yellow solid. Yield 67\%; m.p. 101.9-104.7 ${ }^{\circ} \mathrm{C}$; IR (ATR-Ge, cm ${ }^{-1}$ ): 3368, 3317, 1666 (C=O, CONH); ${ }^{1} \mathrm{H}-\mathrm{NMR}\left(500 \mathrm{MHz}, \mathrm{CDCl}_{3}\right) \delta$ 9.03 (bs, $1 \mathrm{H}, \mathrm{NH}), 8.34$ (bs, $1 \mathrm{H}, \mathrm{NH}), 8.20$ (d, $J=2.4 \mathrm{~Hz}, 1 \mathrm{H}$, pyr.), 7.74 (d, $J=2.5 \mathrm{~Hz}, 1 \mathrm{H}$, pyr.), 7.46-7.37 (m, $4 \mathrm{H}, \mathrm{Ar}), 7.28-7.18(\mathrm{~m}, 2 \mathrm{H}, \mathrm{Ar}), 4.68\left(\mathrm{~d}, J=6.0 \mathrm{~Hz}, 2 \mathrm{H}, \mathrm{CH}_{2}\right), 4.56\left(\mathrm{~d}, J=6.3 \mathrm{~Hz}, 2 \mathrm{H}, \mathrm{CH}_{2}\right) ;{ }^{13} \mathrm{C}-\mathrm{NMR}$ $\left(126 \mathrm{MHz}, \mathrm{CDCl}_{3}\right) \delta 166.46,154.29,146.61,139.40,138.30,132.78,132.49,131.59,131.00,130.66,130.42$, $130.34,129.48,129.38,126.91,126.77,126.22,43.24,42.06$; Elemental analysis: calc. for $\mathrm{C}_{19} \mathrm{H}_{14} \mathrm{Cl}_{4} \mathrm{~N}_{4} \mathrm{O}$ (MW 456.15): $50.03 \%$ C, 3.09\% H, $12.28 \% \mathrm{~N}$; found $50.09 \% \mathrm{C}, 3.22 \% \mathrm{H}, 11.84 \% \mathrm{~N}$.

N-(2-Fluorobenzyl)-3-((2-fluorobenzyl)amino)pyrazine-2-carboxamide (10a). Pale yellow solid. Yield 84\%; m.p. 94.8-95.9 ${ }^{\circ} \mathrm{C}$; IR (ATR-Ge, $\mathrm{cm}^{-1}$ ): 3375, 3349, $1652(\mathrm{C}=\mathrm{O}, \mathrm{CONH}){ }^{1} \mathrm{H}-\mathrm{NMR}\left(500 \mathrm{MHz}, \mathrm{CDCl}_{3}\right) \delta$ $9.00(\mathrm{t}, J=5.5 \mathrm{~Hz}, 1 \mathrm{H}, \mathrm{NH}), 8.30(\mathrm{t}, J=6.1 \mathrm{~Hz}, 1 \mathrm{H}, \mathrm{NH}), 8.19$ (d, $J=2.2 \mathrm{~Hz}, 1 \mathrm{H}, \mathrm{pyr}.), 7.69(\mathrm{~d}, J=2.2 \mathrm{~Hz}$, $1 \mathrm{H}$, pyr.), 7.42-7.36 (m, 2H, Ar), 7.31-7.21 (m, 2H, Ar), 7.15-7.08 (m, 4H, Ar), 4.78 (d, J = 5.5 Hz, 2H, $\left.\mathrm{CH}_{2}\right), 4.66\left(\mathrm{~d}, J=6.1 \mathrm{~Hz}, 2 \mathrm{H}, \mathrm{CH}_{2}\right) ;{ }^{13} \mathrm{C}-\mathrm{NMR}\left(125 \mathrm{MHz} \mathrm{CDCl}_{3}\right) \delta 166.4,161.0(\mathrm{~d}, J=247.0 \mathrm{~Hz}), 154.5$, $146.5,130.0(\mathrm{~d}, J=3.9 \mathrm{~Hz}), 129.9,129.5(\mathrm{~d}, J=3.9 \mathrm{~Hz}), 129.3(\mathrm{~d}, J=7.7 \mathrm{~Hz}), 128.7(\mathrm{~d}, J=7.7 \mathrm{~Hz})$, 126.4, $125.9(\mathrm{~d}, J=14.3 \mathrm{~Hz}), 125.0(\mathrm{~d}, J=14.3 \mathrm{~Hz}), 124.3(\mathrm{~d}, J=3.8 \mathrm{~Hz}), 124.0(\mathrm{~d}, J=2.9 \mathrm{~Hz}), 115.5(\mathrm{~d}$, $J=19.1 \mathrm{~Hz}), 115.3(\mathrm{~d}, J=19.1 \mathrm{~Hz}), 38.1(\mathrm{~d}, J=4.8 \mathrm{~Hz}), 37.1(\mathrm{~d}, J=3.9 \mathrm{~Hz})$; Elemental analysis: calc. for $\mathrm{C}_{19} \mathrm{H}_{16} \mathrm{~F}_{2} \mathrm{~N}_{4} \mathrm{O}$ (MW 354.36): $64.40 \%$ C, $4.55 \% \mathrm{H}, 15.81 \% \mathrm{~N}$; found $64.24 \% \mathrm{C}, 4.49 \% \mathrm{H}, 15.97 \% \mathrm{~N}$.

N-(4-Fluorobenzyl)-3-((4-fluorobenzyl)amino)pyrazine-2-carboxamide (11a). Yellow-brown solid. Yield 75\%; m.p. 97.1-99.1 ${ }^{\circ} \mathrm{C}$; IR (ATR-Ge, $\mathrm{cm}^{-1}$ ): 3378, 3345, 1650 (C=O, CONH); ${ }^{1} \mathrm{H}-\mathrm{NMR}\left(500 \mathrm{MHz}, \mathrm{CDCl}_{3}\right.$ ) 反 9.06-9.00 (m, 1H, NH), 8.31-8.25 (m, 1H, NH), 8.20 (d, J = 2.4 Hz, 1H, pyr.), 8.69 (d, J = 2.4 Hz, $1 \mathrm{H}$, pyr.), 7.37-7.29 (m, 4H, Ar), 7.06-6.99 (m, 4H, Ar), $4.69\left(\mathrm{~d}, J=6.1 \mathrm{~Hz}, 2 \mathrm{H}, \mathrm{CH}_{2}\right), 4.56(\mathrm{~d}, J=6.1 \mathrm{~Hz}, 2 \mathrm{H}$, $\left.\mathrm{CH}_{2}\right) ;{ }^{13} \mathrm{C}-\mathrm{NMR}\left(125 \mathrm{MHz}, \mathrm{CDCl}_{3}\right) \delta 166.4,162.2(\mathrm{~d}, J=246.1 \mathrm{~Hz}), 162.0(\mathrm{~d}, J=245.1 \mathrm{~Hz}), 154.5,146.5$, $134.6(\mathrm{~d}, J=3.9 \mathrm{~Hz}), 133.8(\mathrm{~d}, J=2.9 \mathrm{~Hz}), 129.7,129.3(\mathrm{~d}, J=8.7 \mathrm{~Hz}), 129.1(\mathrm{~d}, J=8.5 \mathrm{~Hz}), 126.4,115.6(\mathrm{~d}$, $J=22.0 \mathrm{~Hz}), 115.3(\mathrm{~d}, J=21.0 \mathrm{~Hz}), 43.6,42.4$; Elemental analysis: calc. for $\mathrm{C}_{19} \mathrm{H}_{16} \mathrm{~F}_{2} \mathrm{~N}_{4} \mathrm{O}$ (MW 354.36): $64.40 \%$ C, $4.55 \% \mathrm{H}, 15.81 \% \mathrm{~N}$; found $64.55 \% \mathrm{C}, 4.41 \% \mathrm{H}, 15.63 \% \mathrm{~N}$.

$\mathrm{N}$-(4-(Trifluoromethyl)benzyl)-3-((4-(trifluoromethyl)benzyl)amino)pyrazine-2-carboxamide (13a). Yellow solid. Yield 86\%; m.p. 99.7-102.5 ${ }^{\circ} \mathrm{C}$; IR (ATR-Ge, $\mathrm{cm}^{-1}$ ): 3388, 3334, 1652 (C=O, CONH); ${ }^{1} \mathrm{H}-\mathrm{NMR}$ $\left(500 \mathrm{MHz}, \mathrm{CDCl}_{3}\right) \delta 9.08(\mathrm{t}, J=5.6 \mathrm{~Hz}, 1 \mathrm{H}, \mathrm{NH}), 8.38(\mathrm{t}, J=6.3 \mathrm{~Hz}, 1 \mathrm{H}, \mathrm{NH}), 8.20(\mathrm{~d}, J=2.4 \mathrm{~Hz}, 1 \mathrm{H}$, pyr.), 7.73 (d, J = 2.4 Hz, 1H, pyr.), 7.64-7.57 (m, 4H, Ar), 7.50-7.45 (m, 4H, Ar), 4.79 (d, J = 5.6 Hz, 2H, $\left.\mathrm{CH}_{2}\right), 4.67\left(\mathrm{~d}, J=6.3 \mathrm{~Hz}, 2 \mathrm{H}, \mathrm{CH}_{2}\right) ;{ }^{13} \mathrm{C}-\mathrm{NMR}\left(125 \mathrm{MHz}, \mathrm{CDCl}_{3}\right) \delta 166.6,154.5$ 146.8, 143.2, 142.1, 130.3, $129.6(\mathrm{q}, J=32.4 \mathrm{~Hz}), 129.6(\mathrm{q}, J=32.4 \mathrm{~Hz}), 127.8,127.6,126.2,125.7(\mathrm{q}, J=3.8 \mathrm{~Hz}), 125.5(\mathrm{q}, J=3.8 \mathrm{~Hz})$, $121.1(\mathrm{q}, J=276.9 \mathrm{~Hz}), 124.0(\mathrm{q}, J=271.8 \mathrm{~Hz}), 43.9,42.7$; Elemental analysis: calc. for $\mathrm{C}_{21} \mathrm{H}_{16} \mathrm{~F}_{6} \mathrm{~N}_{4} \mathrm{O}$ (MW 454.38): $55.51 \%$ C, 3.55\% H, $12.33 \% \mathrm{~N}$; found $55.47 \% \mathrm{C}, 3.68 \% \mathrm{H}, 12.17 \% \mathrm{~N}$.

\subsection{Methods}

\subsubsection{Determination of Lipophilicity by HPLC $(\log k)$}

Log $k$ was determined using an Agilent Technologies 1200 SL liquid chromatograph with Diode-array Detector SL G1315C (Agilent Technologies Inc., Colorado Springs, CO, USA), with 
pre-column ZORBAX XDB-C18 $5 \mu \mathrm{m}, 4 \mathrm{~mm} \times 4 \mathrm{~mm}$, Part No. 7995118-504 (Agilent Technologies Inc.) and column ZORBAX Eclipse XDB-C18 $5 \mu \mathrm{m}, 4.6 \mathrm{~mm} \times 250 \mathrm{~mm}$, Part No. 7995118-585 (Agilent Technologies Inc.). The separation process was controlled by Agilent ChemStation, version B.04.02, extended by a spectral module (Agilent Technologies Inc.). The mobile phase consisted of $\mathrm{MeOH}$ (HPLC grade, $70 \%$ ) and $\mathrm{H}_{2} \mathrm{O}$ (HPLC-Milli-Q Grade, 30\%).

The flow rate was $1.0 \mathrm{~mL} / \mathrm{min}$, samples were injected in a volume of $20 \mu \mathrm{L}$, and the column temperature was $30{ }^{\circ} \mathrm{C}$. A value of $210 \mathrm{~nm}$ as the detection wavelength and $270 \mathrm{~nm}$ as the monitor wavelength were used. Retention times $\left(t_{R}\right)$ were measured in minutes. The dead time of the system $\left(t_{D}\right)$ was determined as the retention time of the KI methanol solution. Capacity factors $k$ for individual compounds were calculated according to the formula $k=\left(t_{R}-t_{D}\right) / t_{D}$. Log $k$, calculated from the capacity factor $k$, as used as the lipophilicity index converted to log scale.

\subsubsection{Evaluation of In Vitro Antimycobacterial Activity}

Microdilution panel method. Tested strains Mycobacterium tuberculosis H37Rv CNCTC My 331/88, M. kansasii Hauduroy CNCTC My 235/80, and M. avium ssp. avium Chester CNCTC My 80/72 were obtained from the Czech National Collection of Type Cultures (CNCTC), National Institute of Public Health, Prague, Czech Republic. Middlebrook 7H9 broth (Sigma-Aldrich, Steinheim, Germany) enriched with the $0.4 \%$ of glycerol (Sigma-Aldrich) and $10 \%$ of OADC supplement (oleic acid, albumin, dextrose, catalase; Himedia, Mumbai, India) of declared $\mathrm{pH}=6.6$ was used for cultivation. Tested compounds were dissolved and diluted in DMSO and mixed with broth $(25 \mu \mathrm{L}$ of DMSO solution in $4.475 \mathrm{~mL}$ of broth) and placed (100 $\mu \mathrm{L})$ into microplate wells. Mycobacterial inocula were suspended in isotonic saline solution and the density was adjusted to $0.5-1.0 \mathrm{McF}$ arland. These suspensions were diluted by $10^{-1}$ and used to inoculate the testing wells, adding $100 \mu \mathrm{L}$ of suspension to $100 \mu \mathrm{L}$ of the DMSO/broth solution of tested compound. Final concentrations of the tested compounds in wells were $100,50,25,12.5,6.25,3.13$, and $1.56 \mu \mathrm{g} \cdot \mathrm{mL}^{-1}$. Isoniazid was used as the positive control (inhibition of growth). The negative control consisted of broth plus DMSO. A total of $30 \mu \mathrm{L}$ of Alamar Blue working solution (1:1 mixture of $0.1 \%$ resazurin sodium salt (aq. sol.) and $10 \%$ Tween 80 ) was added after five days of incubation. Results were then determined after $24 \mathrm{~h}$ of incubation. The minimum inhibitory concentration (MIC; $\mu \mathrm{g} \cdot \mathrm{mL}^{-1}$ ) was determined as the lowest concentration which prevented the blue to pink colour change. MIC values of isoniazid were $6.25-12.5 \mu \mathrm{g} \cdot \mathrm{mL}^{-1}$ against M. avium, 3.13-12.5 $\mu \mathrm{g} \cdot \mathrm{mL}^{-1}$ against $M$. kansasii, and $0.2 \mu \mathrm{g} \cdot \mathrm{mL}^{-1}$ against $M$. tbc.

\subsubsection{Antimycobacterial In Vitro Activity Screening Against Mycobacterium Smegmatis}

An antimycobacterial assay was performed with fast growing Mycobacterium smegmatis CCM 4622 (ATCC 607) from the Czech Collection of Microorganisms (Brno, Czech Republic). The technique used for activity determination was a microdilution broth panel method using 96-well microtitration plates. The culturing medium was Middlebrook 7H9 (MB) broth (Sigma-Aldrich), enriched with 0.4\% of glycerol (Sigma-Aldrich) and 10\% of Middlebrook OADC growth supplement (Himedia, Mumbai, India). Tested compounds were dissolved in DMSO (Sigma-Aldrich), and the MB broth was then added to obtain a concentration of $2000 \mu \mathrm{g} \cdot \mathrm{mL}^{-1}$. Standards used for activity determination were isoniazid (INH), rifampicin (RIF), and ciprofloxacin (CPX) (Sigma-Aldrich). Final concentrations were reached by binary dilution and the addition of mycobacterial suspension, and were set as 500, 250, 125, $62.5,31.25,15.625,7.81$, and $3.91 \mu \mathrm{g} \cdot \mathrm{mL}^{-1}$, except for the standards of ciprofloxacin and rifampicin, where the final concentrations were $12.5,6.25,3.125,1.56,0.78,0.39,0.195$, and $0.098 \mu \mathrm{g} \cdot \mathrm{mL}^{-1}$. The final concentration of DMSO did not exceeded $2.5 \%(v / v)$ and did not affect the growth of M. smegmatis. Plates were also sealed with polyester adhesive film and incubated in the dark at $37^{\circ} \mathrm{C}$, without agitation. The addition of $0.01 \%$ solution of resazurin sodium salt followed after $48 \mathrm{~h}$. This stain was prepared by dissolving resazurin sodium salt (Sigma-Aldrich) in deionised water, producing a $0.02 \%$ solution. Then, a $10 \%$ aqueous solution of Tween 80 (Sigma-Aldrich) was prepared. Both liquids were mixed up making use of the same volumes and filtered through a syringe membrane 
filter. Microtitration panels were then incubated for a further $4 \mathrm{~h}$. Antimycobacterial activity was expressed as the minimal inhibition concentration (MIC) and the value was read on the basis of stain colour change (blue colour-active compound; pink colour-not active compound). The MIC values for the standards were in the range of $7.81-15.625 \mu \mathrm{g} \cdot \mathrm{mL}^{-1}$ for INH, $0.78-1.56 \mu \mathrm{g} \cdot \mathrm{mL}^{-1}$ for RIF, and $0.098-0.195 \mu \mathrm{g} \cdot \mathrm{mL}^{-1}$ for CPX. All experiments were conducted in duplicate.

\subsubsection{Evaluation of In Vitro Antibacterial Activity}

Microdilution broth method. Antibacterial evaluation was performed against eight bacterial strains from the Czech Collection of Microorganisms (Brno, Czech Republic) (Staphylococcus aureus CCM 4516/08, Escherichia coli CCM 4517, Pseudomonas aeruginosa CCM 1961) or clinical isolates from the Department of Clinical Microbiology, University Hospital and Faculty of Medicine in Hradec Králové, Charles University in Prague, Czech Republic (Staphylococcus aureus H 5996/08-methicilin resistant (MRSA), Staphylococcus epidermidis H 6966/08, Enterococcus sp. J 14365/08, Klebsiella pneumoniae D 11750/08, Klebsiella pneumoniae J 14368/08-ESBL positive). All strains were subcultured on Mueller-Hinton agar (MHA) (Difco/Becton Dickinson, Detroit, MI, USA) at $35^{\circ} \mathrm{C}$ and maintained on the same medium at $4{ }^{\circ} \mathrm{C}$. The compounds were dissolved in DMSO, and the antibacterial activity was determined in Mueller-Hinton liquid broth (Difco/Becton Dickinson), and buffered to pH 7.0. Controls consisted of medium and DMSO alone. The final concentration of DMSO in the test medium did not exceed $1 \%(v / v)$ of the total solution composition. The minimum inhibitory concentration (MIC), defined as the minimum concentration to prevent the visible growth compared to control, was determined after 24 and $48 \mathrm{~h}$ of static incubation at $35^{\circ} \mathrm{C}$. The standards were neomycin, bacitracin, penicillin $\mathrm{G}$, ciprofloxacin, and phenoxymethylpenicillin.

\subsubsection{Evaluation of In Vitro Antifungal Activity}

Antifungal evaluation was performed using a microdilution broth method against eight fungal strains (Candida albicans ATCC 44859, C. tropicalis 156, C. krusei E28, C. glabrata 20/I, Trichosporon asahii 1188, Aspergillus fumigatus 231, Lichtheimia corymbifera 272 and Trichophyton mentagrophytes 445). Compounds were dissolved in DMSO and diluted in a twofold manner with RPMI 1640 medium, with glutamine buffered to $\mathrm{pH} 7.0$ (3-morpholinopropane-1-sulfonic acid). The final concentration of DMSO in the tested medium did not exceed $2.5 \%(v / v)$ of the total solution composition. Static incubation was performed in the dark and humid, at $35^{\circ} \mathrm{C}$, for 24 and $48 \mathrm{~h}$ (respectively 72 and $120 \mathrm{~h}$ for Trichophyton mentagrophytes). Drug-free controls were included. The standards were amphotericin $\mathrm{B}$, voriconazole, nystatin, and fluconazole.

\subsubsection{Cytotoxicity Assays}

The human liver hepatocellular carcinoma cell line HepG2 (passage 35-36), purchased from Health Protection Agency Culture Collections (ECACC, Salisbury, UK), was routinely cultured in Minimum Essential Eagle Medium MEM (Sigma-Aldrich) supplemented with 10\% fetal bovine serum (PAA Laboratories GmbH, Pasching, Austria), 2mM L-glutamine solution (Sigma-Aldrich), and 1\% non-essential amino acid solution (Sigma-Aldrich), in a humidified atmosphere containing $5 \% \mathrm{CO}_{2}$ at $37^{\circ} \mathrm{C}$.

For subculturing, the cells were harvested after trypsin/EDTA (Sigma-Aldrich) treatment at $37^{\circ} \mathrm{C}$. To evaluate the cytotoxicity, the HepG2 cells treated with the tested substances were used as experimental groups, whereas untreated HepG2 cells served as control groups.

The HepG2 cells were seeded in a density of $1 \times 10^{4}$ cells per well on a 96-well plate. The following day ( $24 \mathrm{~h}$ after seeding), they were treated with tested substances dissolved in DMSO (maximal incubation concentration of DMSO was 1\%). The tested substances were prepared according to their solubility in DMSO, at incubation concentrations of 1-2500 $\mu \mathrm{M}$. The treatment was carried out in a humidified atmosphere containing $5 \% \mathrm{CO}_{2}$ at $37{ }^{\circ} \mathrm{C}$, in triplicate, for $24 \mathrm{~h}$. The controls representing $100 \%$ cell viability, $0 \%$ cell viability (the cells treated with 10\% DMSO), no-cell controls, 
and vehiculum controls were incubated in triplicate, simultaneously. After $24 \mathrm{~h}$ exposure, the reagent from the kit CellTiter $96^{\circledR}$ Aqueous One Solution Cell Proliferation Assay (Promega) was added, according to the recommendation of the manufacturer. After $2 \mathrm{~h}$ incubation at $37^{\circ} \mathrm{C}$ in humidified, $5 \% \mathrm{CO}_{2}$ atmosphere, the absorbance was recorded at $490 \mathrm{~nm}$. Inhibitory curves were constructed for each compound, plotting incubation concentrations vs. percentage of absorbance relative to untreated control. The standard toxicological parameter $\mathrm{IC}_{50}$ was calculated by a nonlinear regression analysis of the inhibitory curves using GraphPad Prism software (version 6, GraphPad Software, Inc., La Jolla, CA, USA).

\section{Conclusions}

Thirteen new N-benzyl-3-chloropyrazine-2-carboxamide derivatives and ten N-benzyl-3(benzylamino)pyrazine-2-carboxamide derivatives were prepared and analytically characterized. Further, antimycobacterial, antibacterial, and antifungal assays were performed. Compounds 1-13 presented in this paper were prepared for the purpose of completing series of 5- and 6-positional isomers, as reported previously. However, the chlorine shift to position 3 on the pyrazine ring led to the decrease of antimycobacterial activity compared to 5- or 6-positional isomers. Contrary to $5-\mathrm{Cl}$ and $6-\mathrm{Cl}$ positional isomers, $\mathrm{N}$-benzyl-3-chloropyrazine-2-carboxamides exerted antibacterial activity against staphylococcal strains. The most effective compound was 5 , with micromolar activity against Staphylococcus aureus and Staphylococcus epidermidis. Interestingly, some initially unplanned side products with double benzyl substitution possessed better antimycobacterial activity than the intended $\mathrm{N}$-benzyl-3-chloropyrazine-2-carboxamides. From compounds with double phenyl substitution, 1a and 9a exerted moderate antimycobacterial activity (tens of $\mu \mathrm{M}$ ) and 3a was moderately active against methicillin-resistant Staphylococcus aureus (tens of $\mu \mathrm{M}$ ). Generally, the insertion of the second aromatic ring was beneficial to the activity against $M$. tuberculosis $\mathrm{H} 37 \mathrm{Rv}$, but contra-productive for activity against $M$. smegmatis and other tested bacteria. Importantly, the discussed active compounds were assayed for in vitro cytotoxicity with plausible results.

Supplementary Materials: The docking studies are available online.

Acknowledgments: This study was supported by the Grant Agency of Charles University B-CH/1594214, SVV 260401 and by the Czech Science Foundation project No. 17-27514Y.

Author Contributions: L.S. synthetized the compounds; L.S. and J.Z. designed the structures, evaluated the biological activity, and wrote the paper; O.J. and P.P. performed the antimycobacterial assays; K.K. performed the antibacterial and antifungal assays; L.N. and F.T. conceived and performed the cytotoxicity; V.K. performed and evaluated the lipophilicity measurements; J.K. interpreted the NMR spectra; and M.D. participated in the structure design.

Conflicts of Interest: The authors declare no conflict of interest.

\section{References}

1. O'Connell, K.M.G.; Hodgkinson, J.T.; Sore, H.F.; Welch, M.; Salmond, G.P.C.; Spring, D.R. Combating Multidrug-Resistant Bacteria: Current Strategies for the Discovery of Novel Antibacterials. Angew. Chem. Int. Ed. 2013, 52, 10706-10733. [CrossRef] [PubMed]

2. World Health Organisation. Global Action Plan on Antimicrobial Resistance; WHA68/2015/REC/1; World Health Organisation: Geneva, Switzerland, 2015. Available online: http://www.who.int/antimicrobialresistance/publications/global-action-plan/en/ (accessed on 16 January 2017).

3. World Health Organization. Global Tuberculosis Report 2016; WHA68/2015/REC/1; World Health Organisation: Geneva, Switzerland, 2016. Available online: http://www.who.int/tb/publications/global_ report/en/ (accessed on 16 January 2017).

4. Servusova-Vanaskova, B.; Jandourek, O.; Paterova, P.; Kordulakova, J.; Plevakova, M.; Kubicek, V.; Kucera, R.; Garaj, V.; Naesens, L.; Kunes, J.; et al. Alkylamino derivatives of N-Benzylpyrazine-2-carboxamide: Synthesis and antimycobacterial evaluation. MedChem Comm 2015, 6, 1311-1317. [CrossRef] 
5. Lima, C.H.S.; Henriques, M.G.M.O.; Candea, A.L.P.; Lourenco, M.C.S.; Bezerra, F.A.F.M.; Ferreira, M.L.; Kaiser, C.R.; de Souza, M.V.N. Synthesis and Antimycobacterial Evaluation of $N^{\prime}$-(E)-heteroaromaticpyrazine-2-carbohydrazide Derivatives. Med. Chem. 2011, 7, 245-249. [CrossRef] [PubMed]

6. Zimhony, O.; Vilcheze, C.; Arai, M.; Welch, J.T.; Jacobs, W.R. Pyrazinoic acid and its n-propyl ester inhibit fatty acid synthase type I in replicating tubercle bacilli. Antimicrob. Agents Chemother. 2007, 51, 752-754. [CrossRef] [PubMed]

7. Fernandes, J.P.D.; Pavan, F.R.; Leite, C.Q.F.; Felli, V.M.A. Synthesis and evaluation of a pyrazinoic acid prodrug in Mycobacterium tuberculosis. Saudi Pharm. J. 2014, 22, 376-380. [CrossRef] [PubMed]

8. Singh, P.; Mishra, A.K.; Malonia, S.K.; Chauhan, D.S.; Sharma, V.D.; Venkatesan, K.; Katoch, V.M. The paradox of pyrazinamide: An update on the molecular mechanisms of pyrazinamide resistance in Mycobacteria. J. Commun. Dis. 2006, 38, 288-298. [PubMed]

9. Shi, W.; Zhang, X.; Jiang, X.; Yuan, H.; Lee, J.S.; Barry, C.E, III; Wang, H.; Zhang, W.; Zhang, Y. Pyrazinamide Inhibits Trans-Translation in Mycobacterium tuberculosis. Science 2011, 333, 1630-1632. [CrossRef] [PubMed]

10. Sayahi, H.; Pugliese, K.M.; Zimhony, O.; Jacobs, W.R., Jr.; Shekhtman, A.; Welch, J.T. Analogs of the Antituberculous Agent Pyrazinamide Are Competitive Inhibitors of NADPH Binding to M. tuberculosis Fatty Acid Synthase I. Chem. Biodivers. 2012, 9, 2582-2596. [CrossRef] [PubMed]

11. Shi, W.; Chen, J.; Feng, J.; Cui, P.; Zhang, S.; Weng, X.; Zhang, W.; Zhang, Y. Aspartate decarboxylase (PanD) as a new target of pyrazinamide in Mycobacterium tuberculosis. Emerg. Microbes Infect. 2014, 3, e58. [CrossRef] [PubMed]

12. Kalinda, A.S.; Aldrich, C.C. Pyrazinamide: A Frontline Drug Used for Tuberculosis. Molecular Mechanism of Action Resolved after 50 Years? ChemMedChem 2012, 7, 558-560. [CrossRef] [PubMed]

13. Servusova, B.; Eibinova, D.; Dolezal, M.; Kubicek, V.; Paterova, P.; Pesko, M.; Kral'ova, K. Substituted N-Benzylpyrazine-2-carboxamides: Synthesis and Biological Evaluation. Molecules 2012, 17, 13183-13198. [CrossRef] [PubMed]

14. Servusova, B.; Vobickova, J.; Paterova, P.; Kubicek, V.; Kunes, J.; Dolezal, M.; Zitko, J. Synthesis and antimycobacterial evaluation of $\mathrm{N}$-substituted 5-chloropyrazine-2-carboxamides. Bioorg. Med. Chem. Lett. 2013, 23, 3589-3591. [CrossRef] [PubMed]

15. Semelkova, L.; Konecna, K.; Paterova, P.; Kubicek, V.; Kunes, J.; Novakova, L.; Marek, J.; Naesens, L.; Pesko, M.; Kralova, K.; et al. Synthesis and Biological Evaluation of N-Alkyl-3-(alkylamino)-pyrazine2-carboxamides. Molecules 2015, 20, 8687-8711. [CrossRef] [PubMed]

16. Zitko, J.; Dolezal, M. Enoyl acyl carrier protein reductase inhibitors: An updated patent review (2011-2015). Expert Opin. Ther. Pat. 2016, 26, 1079-1094. [CrossRef] [PubMed]

17. Jampilek, J.; Dolezal, M.; Kunes, J.; Satinsky, D.; Raich, I. Novel regioselective preparation of 5-chloropyrazine-2-carbonitrile from pyrazine-2-carboxamide and coupling study of substituted phenylsulfanylpyrazine-2-carboxylic acid derivatives. Curr. Org. Chem. 2005, 9, 49-60. [CrossRef]

18. Jandourek, O.; Dolezal, M.; Paterova, P.; Kubicek, V.; Pesko, M.; Kunes, J.; Coffey, A.; Guo, J.; Kralova, K. N-Substituted 5-Amino-6-methylpyrazine-2,3-dicarbonitriles: Microwave-Assisted Synthesis and Biological Properties. Molecules 2014, 19, 651-671. [CrossRef] [PubMed]

Sample Availability: Samples of the compounds 1-13 and 1a-13a are available from the authors.

(C) 2017 by the authors. Licensee MDPI, Basel, Switzerland. This article is an open access article distributed under the terms and conditions of the Creative Commons Attribution (CC BY) license (http:/ / creativecommons.org/licenses/by/4.0/). 